\title{
Geology, Geography, and Humans Battle for Dominance over the Delivery of Fluvial Sediment to the Coastal Ocean
}

James P.M. Syvitski

John D. Milliman

Virginia Institute of Marine Science

Follow this and additional works at: https://scholarworks.wm.edu/vimsarticles

Part of the Geology Commons

\section{Recommended Citation}

Syvitski, James P.M. and Milliman, John D., "Geology, Geography, and Humans Battle for Dominance over the Delivery of Fluvial Sediment to the Coastal Ocean" (2007). VIMS Articles. 1824.

https://scholarworks.wm.edu/vimsarticles/1824 


\title{
ARTICLES
}

\section{Geology, Geography, and Humans Battle for Dominance over the Delivery of Fluvial Sediment to the Coastal Ocean}

\author{
James P. M. Syvitski and John D. Milliman ${ }^{1}$ \\ Environmental Computation and Imaging Facility, Institute of Arctic and Alpine Research, \\ University of Colorado, Boulder, Colorado 80309-0450, U.S.A. \\ (e-mail: syvitski@colorado.edu)
}

\begin{abstract}
A B S T R A C T
Sediment flux to the coastal zone is conditioned by geomorphic and tectonic influences (basin area and relief), geography (temperature, runoff), geology (lithology, ice cover), and human activities (reservoir trapping, soil erosion). A new model, termed "BQART" in recognition of those factors, accounts for these varied influences. When applied to a database of 488 rivers, the BQART model showed no ensemble over- or underprediction, had a bias of just $3 \%$ across six orders of magnitude in observational values, and accounted for $96 \%$ of the between-river variation in the long-term ( \pm 30 years) sediment load or yield of these rivers. The geographical range of the 488 rivers covers $63 \%$ of the global land surface and is highly representative of global geology, climate, and socioeconomic conditions. Based strictly on geological parameters (basin area, relief, lithology, ice erosion), $65 \%$ of the between-river sediment load is explained. Climatic factors (precipitation and temperature) account for an additional $14 \%$ of the variability in global patterns in load. Anthropogenic factors account for an additional $16 \%$ of the between-river loads, although with ever more dams being constructed or decommissioned and socioeconomic conditions and infrastructure in flux, this contribution is temporally variable. The glacial factor currently contributes only $1 \%$ of the signal represented by our globally distributed database, but it would be much more important during and just after major glaciations. The BQART model makes possible the quantification of the influencing factors (e.g., climate, basin area, ice cover) within individual basins, to better interpret the terrestrial signal in marine sedimentary records. The BQART model predicts the long-term flux of sediment delivered by rivers; it does not predict the episodicity (e.g., typhoons, earthquakes) of this delivery.
\end{abstract}

Online enhancement: appendix table.

\section{Introduction}

Sediment flux to the coastal zone is conditioned by geomorphic and tectonic influences within the world's drainage basins (Milliman and Syvitski 1992) but also by geography of the basin (location and climate), geology, and human activities. These often counterbalancing factors have complicated our understanding of what controls sediment discharge to the global ocean (Hay 1994). A recent survey (Syvitski et al. 2005a), found globally that soil erosion is accelerating (e.g., deforestation, ag-

\footnotetext{
Manuscript received January 9, 2006; accepted July 11, 2006.

${ }^{1}$ School of Marine Science, College of William \& Mary, Gloucester Point, Virginia 23062, U.S.A.; e-mail: milliman@ vims.edu.
}

riculture, mining), while at the same time, sediment flux to the coastal zone is decelerating (e.g., channel bank hardening, water diversion, reservoir storage). Another factor that complicates our understanding of a river's conveyance of sediment to the coast is the variable quality and relatively short duration of observations, where coverage is often measured in years rather than decades (Syvitski 2003c).

Despite these complications, the importance of understanding fluvial delivery of sediment is beyond question. Understanding the redistribution of continental substrate through weathering and erosion is one of the fundamental goals of geological sciences. The redistribution of material loads (1) 
reflects the rate of mountain building (Small and Anderson 1995; Molnar 2004), (2) influences the dynamics of glaciers (Boulton 1990), (3) shapes the landscape (Anderson 1994), and (4) affects coastal dynamics through sea-level adjustments and strata formation (Nittrouer 1999; Liu et al. 2004; Berne et al. 2004). In the observational world of today, we can see how human interference with river systems has accelerated coastal erosion and negatively affected wetland and aquatic habitats (Syvitski et al. 2005a). The reduction of seasonal flood waves and the changing composition of water through damming and regulation also mean that nutrients associated with sediment can be dispersed over smaller areas of the continental margin, significantly affecting fisheries and even causing anoxia or hypoxia (Syvitski et al. 2005b).

\section{A Brief History}

Early estimates of sediment loads from rivers were based on data from relatively few large rivers (Holeman 1968; Holland 1981). From these and later studies, the magnitude of a river's sediment load was understood to increase with the size of its drainage area (Schumm and Hadley 1961; Wilson 1973; Milliman 1980; Milliman and Meade 1983). Milliman and Syvitski (1992) demonstrated a strong correlation between sediment load $Q_{\mathrm{s}}$ and basin area $A$, with $Q_{\mathrm{s}}=c A^{d}$ (the coefficients depending on five relief classes; table 1), adding to the fundamental research of Schumm (1965) Ahnert (1970), Jansen and Painter (1974), Hay and Southam (1977), Pinet and Souriau (1988), and Harrison (1994).

One of Milliman and Syvitski's (1992) primary contributions was viewing rivers regardless of size. Mulder and Syvitski (1996) collapsed the M\&S92 family of curves (table 1) by using the maximum relief for a drainage basin $R$, rather than just relief classes. Their multiregression analysis established a single relationship between sediment load, basin area, and maximum relief $R$, such that

$$
Q_{\mathrm{s}}=\alpha A^{0.41} R^{1.3},
$$

where $\alpha$ is a constant of proportionality. Mulder and Syvitski (1996) noted that the correlation improved if rivers with strong human impact were removed. Deviations between observed loads and predictions were offered as a way to decipher the effects of human impact on fluvial systems.

The role of geology as a control on a river's sediment flux also has been noted (Heusch and MilliesLacroix 1971; Pinet and Souriau 1988; Ludwig and
Table 1. Coefficients in the Power Function between Sediment Load $Q_{\mathrm{s}}(\mathrm{MT} / \mathrm{yr})$ and Basin Area $A\left(\mathrm{M} \mathrm{km}^{2}\right)$ $\left(Q_{\mathrm{s}}=c A^{d}\right)^{\mathrm{a}}$

\begin{tabular}{lclll}
\hline River system & $c$ & $d$ & $r^{2}$ & $N$ \\
\hline$>3000 \mathrm{~m}$ & 280 & .46 & .80 & 21 \\
1000-3000 m: & & & & \\
$\quad$ America, Africa, Alps & 170 & .52 & .70 & 41 \\
Asia, Oceania & 65 & .56 & .74 & 90 \\
Northern, polar & 50 & .73 & .78 & 10 \\
$\quad$ Average & 95 & .6 & & 141 \\
500-1000 m & 12 & .42 & .82 & 55 \\
$100-500 \mathrm{~m}$ & 8 & .66 & .81 & 43 \\
$<100 \mathrm{~m}$ & 1 & .64 & .81 & 15 \\
\hline
\end{tabular}

${ }^{a}$ Based on a database developed by Milliman and Syvitski (1992) of 275 globally distributed rivers.

Probst 1998; Inman and Jenkins 1999; Kapsimalis et al. 2005). Hicks et al. (1996), for instance, found that at any given rainfall, New Zealand rivers draining weak sedimentary rocks had sediment yields orders of magnitude greater than those draining strongly metamorphic rocks. Milliman and Syvitski (1992) in effect included geology as a factor affecting flux by subdividing the mountain relief class between, for example, the softer lithology of much of Asia and the hard gneisses and granites covering much of the Arctic region (table 1).

Climate's effect on sediment load is a more complex influence, leading Walling and Webb (1983) to conclude that no simple relationship exists between climate and sediment yield. Sediment yield is considered to both increase (Fournier 1949; Jansen and Painter 1974; Hay et al. 1987) and decrease (Langbein and Schumm 1958; Fournier 1960) with the rate of precipitation, as tracked by a basin's runoff (Walling 1987; Milliman and Syvitski 1992; Mulder and Syvitski 1996). Molnar (2001), for example, has suggested that increased late Tertiary erosion rates were in large part the result of increased global aridity. Basin temperature also can influence a river's sediment load by causing sediment-forming frost cycles, influencing sediment availability through frozen ground conditions, and through feedbacks that influence the magnitude and intensity of precipitation (Syvitski and Morehead 1999; Syvitski 2002). A combination of higher temperature and summer precipitation will increase glacial melt and significantly increase a basin's sediment yield (Andrews and Syvitski 1994; Hallet et al. 1996; Morehead et al. 2001). Other influences on a river's sediment load include vegetation cover that increases or decreases with variations in regional temperature and precipitation (Douglas 1967) and lakes or reservoirs that may filter out a river's sediment load (Vörösmarty et al. 2003). 


\section{Development of the ART model}

Syvitski and Morehead (1999) applied dimensional analysis to the problem of predicting a river basin's long-term sediment load, concentrating on the parameters $Q_{\mathrm{s}}[\mathrm{M} / \mathrm{T}], A\left[\mathrm{~L}^{2}\right], R[\mathrm{~L}]$, fluid density $\rho[\mathrm{M} /$ $\left.\mathrm{L}^{3}\right]$, and gravity $g\left[\mathrm{~L} / \mathrm{T}^{2}\right]$. Relief was determined from cartographic surveys or gridded relief databases. Basin area was determined from the original gauging station metadata. Their analysis recovered two dimensionless supervariables designed to reflect (1) a gravity-driven sediment yield (left side of eq. [2]) and (2) a potential-energy term (right side of eq. [2]), such that

$$
\frac{Q_{\mathrm{s}}}{\rho g^{1 / 2} A^{5 / 4}}=\alpha\left(\frac{R}{A^{1 / 2}}\right)^{n} .
$$

They assumed $n=1.5$, based on equation (1), and thus

$$
Q_{\mathrm{s}}=\alpha \rho g^{1 / 2} A^{1 / 2} R^{3 / 2},
$$

where $\alpha$ is a constant of proportionality; but Syvitski and Morehead (1999) suggested that $\alpha$ varied with basin temperature. Syvitski et al. (2003), in an experiment to test equation (3) for regionality in temperature, divided the river basins by climate: polar, cold temperate, warm temperate, and tropical regions, both north and south of the equator. They found that basin-averaged temperature (fig. 1) did play a role and formally rewrote equation (3) as

$$
Q_{\mathrm{s}}=\alpha_{3} A^{\alpha_{4}} R^{\alpha_{5}} e^{k T},
$$

where $k$ and the various $\alpha^{\prime}$ s are empirical coefficients that define the major climate zones. Basin temperature controls polar feedbacks (frozen soils and river beds, snowmelt and ice melt, predominance of frontal rainfall), temperate feedbacks (spring snowmelt, freeze-thaw cycles, mix of frontal and convective rainfall), and tropical feedbacks (convective rainfall, monsoons, typhoons, chemical weathering and soil formation, tropical canopy, high lapse rates). The model, known as the ART model (fig. 2A), was later shown to reflect preanthropocene or pristine conditions (Syvitski et al. 2005a). Basin area and relief were considered proxies of tectonics, where active and passive margins could be differentiated. Basin temperature, which varies with latitude and altitude, was used as a proxy for climate, and thus the global distribution of precipitation dynamics, vegetation, and weathering.

Syvitski et al. (2003) found that exponent $n$ in equation (2) varied by climate regions, from 0.4 to 1.5. Transitional discontinuities in the predicted values near the climate boundaries were recognized but not addressed. The coefficient $k$ varied between climate zones and was considered indicative of the changing impact of weathering styles (physical to chemical), depending on latitudinal location. Bias in the ART model predictions suggested that other parameters, not included in the model, must affect a river's sediment flux. When the discontinuities between the regions were removed using a globally averaged value of $n=1$ (eq. [2]) and $k=0.13$ (eq. [4]) and applied to global observations on 488 rivers, the climate zone-free ART model accounted for just $57 \%$ of the global variance (fig. $2 B$ ).

\section{New Global Predictor of Sediment Load: The BQART Model}

This article proposes a more comprehensive global predictor of fluvial sediment flux, avoiding discontinuities or regional bias in the predictions and including influences considered important and hitherto left out of equation (4). First we use the globally averaged value of $n=1$ from equation (2):

$$
Q_{\mathrm{s}}=\alpha B A^{3 / 4} R T,
$$

where $\alpha=\gamma \rho g^{1 / 2}, B$ accounts for important geological and human factors missing from the ART model, $R$ is maximum relief, and $T$ is basin-averaged temperature (fig. 1).

Based on a database of 488 rivers, which supply $63 \%$ of the world's total discharge to the coastal ocean, a relationship exists between discharge $Q$ (in $\mathrm{m}^{3} / \mathrm{s}$ ) and drainage area $A$ (in $\mathrm{km}^{2}$; fig. 3 ):

$$
Q=0.075 A^{0.8}
$$

Given equation (6), it can be shown that $A^{3 / 4}=$ $2.25 A^{1 / 2} Q^{0.31}$. Thus equation (5) is rewritten to incorporate both discharge and basin area, assuming that the two variables are partly independent (see isolines of runoff on fig. 3; table 2). The new BQART model is then

$$
\begin{aligned}
& Q_{\mathrm{s}}=\omega B Q^{0.31} A^{0.5} R T \text { for } T \geq 2^{\circ} \mathrm{C}, \\
& Q_{\mathrm{s}}=2 \omega B Q^{0.31} A^{0.5} R \text { for } T<2^{\circ} \mathrm{C},
\end{aligned}
$$

where $Q_{\mathrm{s}}$ is in dimensions of $[\mathrm{M} / \mathrm{T}]$ with $\omega=$ 0.02 for units of $\mathrm{kg} / \mathrm{s}$, or $\omega=0.0006$ for units of $\mathrm{MT} / \mathrm{yr}, Q$ is in $\mathrm{km}^{3} / \mathrm{yr}, A$ is in $\mathrm{km}^{2}, R$ is in $\mathrm{km}$, and $T$ is in ${ }^{\circ} \mathrm{C}$. The partial independence between area and discharge relates to reasons of scale: (1) giant drainage basins, by the nature of their size, incor- 


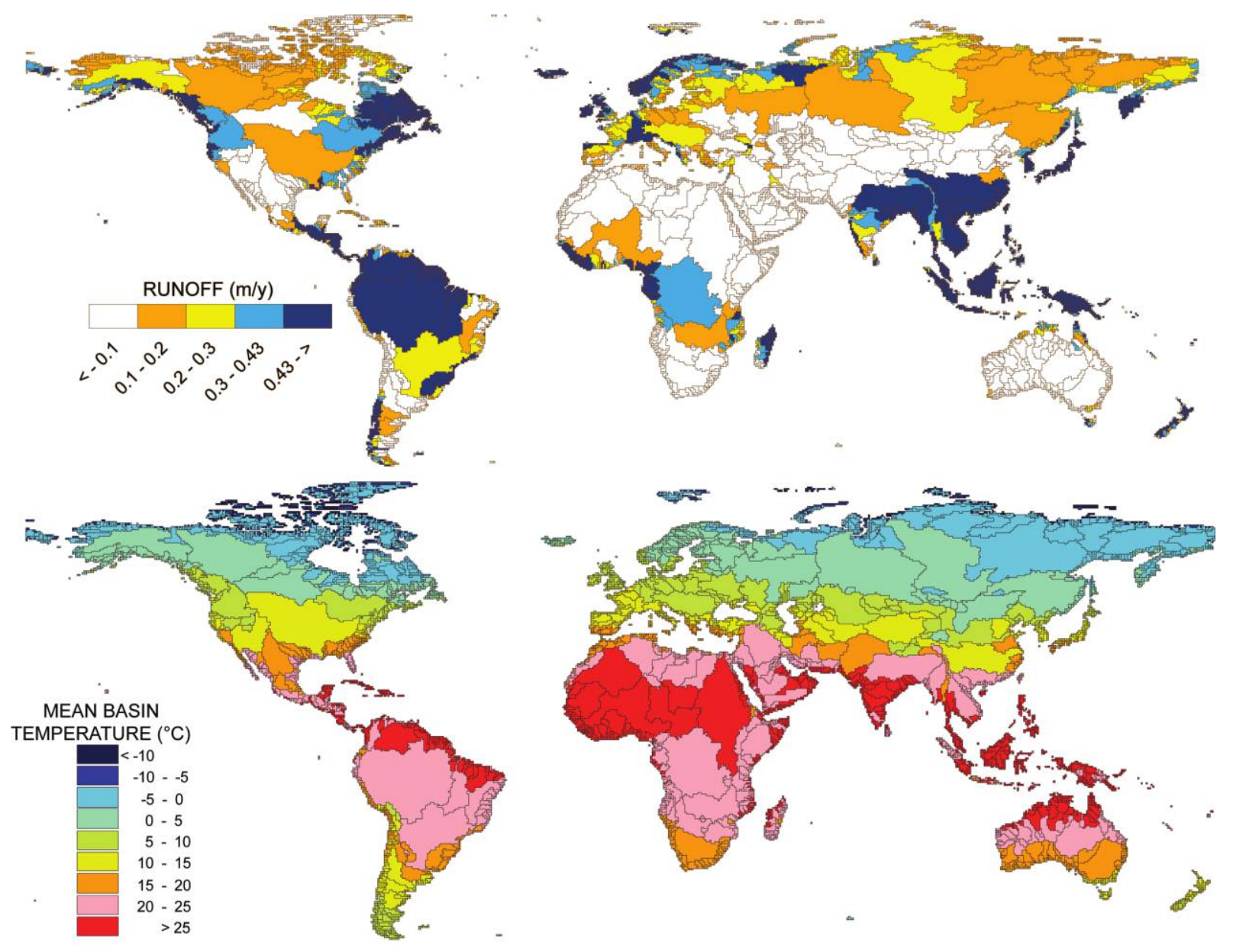

Figure 1. Drainage basin-averaged values of hydrological runoff $(Q / A ; t o p)$ and temperature $(T ;$ bottom) of global river basins, represented at $0.5^{\circ} \times 0.5^{\circ}$ resolution. Basin runoff was determined using data from the Global Runoff Data Centre (Germany), supplemented with the University of New Hampshire water balance transport model (see Syvitski et al. 2005a for details). Basin temperature was calculated from National Centers for Environmental Prediction/National Center for Atmospheric Research reanalysis data made available from the NOAA-CIRES Climate Diagnostic Center (see Syvitski et al. 2003).

porate both wet and dry regions (fig. 1) and have runoff values $<1 \mathrm{~m} / \mathrm{yr}$ (fig. 3); and (2) smaller basins can easily fit within a single hydrological zone and thus can range from very high to very low hydrological runoff (fig. 3).

Given two basins that are comparable in size, relief, and temperature, equation (7) predicts that the wetter one will be more able to erode and transport sediment downstream. Regions of the world where physical processes of erosion are active are also the regions where aluminosilicates dissolve at the highest rate (Gaillardet et al. 1999). Conversely, drier basins produce less sediment through mechanical (as well as chemical) weathering (Dupré et al. 2003), and more of this sediment will be stored between the source area and the coast, thus making such basins "transport limited" (e.g., Wabi Shebele of Ethiopia and Somalia; Nyssen et al. 2004). Most world rivers are arid to subarid, with a hydrological runoff of $Q / A \leq 0.4 \mathrm{~m} / \mathrm{yr}$ (figs. 1, 3), exceptions being tropical basins of Central and South America, Indonesia and other equatorial islands; portions of Southeast Asia; and small coastal basins of North and South America, northern Europe, and eastern Canada (fig. 3). When statistics are based solely on the flowing period, arid rivers fall within the global average (Meybeck et al. 2003). The Santa Clara River in southern California, for example, sees $\sim 75 \%$ of its 50 -yr cumulative sediment load transported in $\sim 0.2 \%$ of the cumulative time (Warrick and Milliman 2003).

The BQART model's other climate factor is 
A

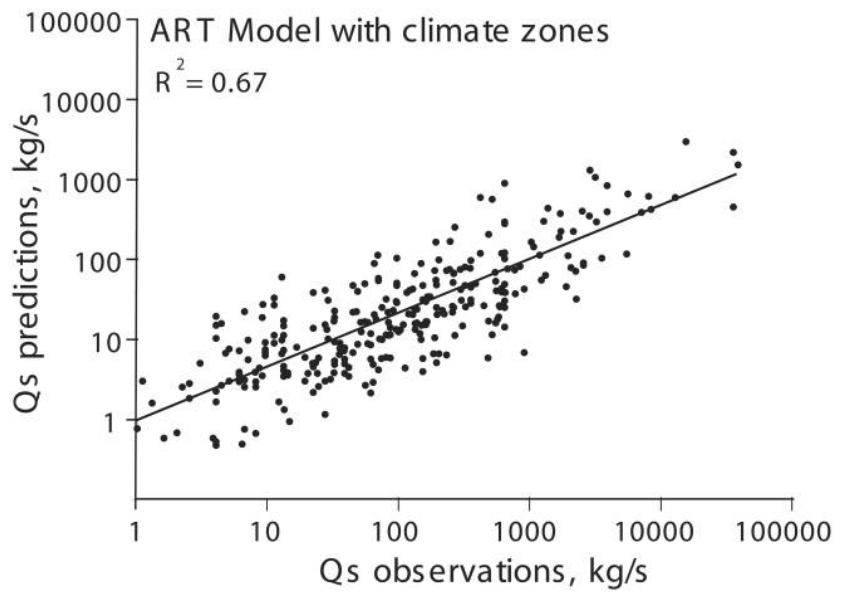

B

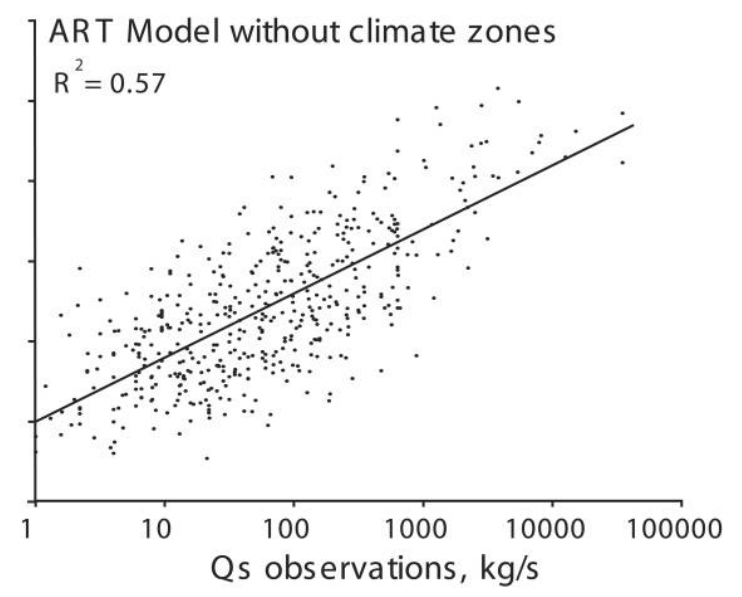

Figure 2. A, ART model based on global climate zones (Syvitski et al. 2003) captures $67 \%$ of the data variance when compared to observations from 327 global rivers. B, ART model without employing climate zones captures $57 \%$ of the data variance when compared to observations from 488 global rivers.

basin-averaged temperature (fig. 1), where warmer temperatures are associated with increased sediment production and increased transport to the coastal ocean. Basin temperature influences (1) the rate of chemical breakdown of the rocks and thus soil formation, (2) the rate of mechanical erosion (frozen soils and river beds, freeze-thaw cycles, precipitation intensity, vegetation influences), (3) latitudinal variation in lapse rate, (4) the storage or release of meltwater, and (5) flood-wave dynamics associated with different forms of rainfall (frontal vs. convective, monsoons, typhoons). The contribution of temperature to sediment discharge is extensively discussed by Syvitski et al. (2003), Syvitski $(2003 b)$, and Dupré et al. (2003). The reason why cold $\left(<2^{\circ} \mathrm{C}\right)$ rivers break with the pattern of a linear decrease in the sediment load with decreasing temperature (eq. [7]) is still under investigation, but Millot et al. (2003) suggest that this reversal in trend may reflect the important role of organic matter as a controlling factor in Arctic regimes.

The $B$ term expanded is defined as

$$
B=I L\left(1-T_{\mathrm{E}}\right) E_{\mathrm{h}},
$$

where $I$ is a glacier erosion factor $(I \geq 1), L$ is an average basin-wide lithology factor, $T_{\mathrm{E}}$ is the trapping efficiency of lakes and man-made reservoirs, such that $\left(1-T_{\mathrm{E}}\right) \leq 1$, and $E_{\mathrm{h}}$ is a human-influenced soil erosion factor, which can provide both a positive or negative influence on a river's sediment flux. Without these new terms, that is, setting $B=1.0$, the BQART model accounts for $68 \%$ of the between-river variation in sediment load (fig. 4), still significantly better than the $57 \%$ accounted for by the ART model (fig. 2). Below we show the influence of the various $B$ factors, beginning first with a description of the river database, followed by a description of the geological and human factors that define each basin.

\section{Defining the Global River Database}

Over the past 25 years, various scientists and agencies have contributed to the development of a number of semi-independent databases that have been used to test sediment flux predictors. The result has been a series of increasingly vetted databases made public in Milliman and Meade (1983), Milliman and Syvitski (1992), Mulder and Syvitski (1996), Meybeck et al. (2003), Walling and Fang (2003), Syvitski et al. (2005a), and Milliman and Farnsworth (forthcoming). Syvitski et al. (2003) and Milliman and Farnsworth (forthcoming) provide an analysis of uncertainties associated with the observations, which, because these databases developed as community effort, contain numerous uncertainties.

Values that define a river in these databases may vary over time for a number of important reasons. For example, there may be discovered errors, such as the Mackenzie load value in Milliman and Syvitski (1992) being out by a decimal place. There may be different criteria used; for example, the drainage area may be tied to an upstream gauging station and not the river mouth cited in another 


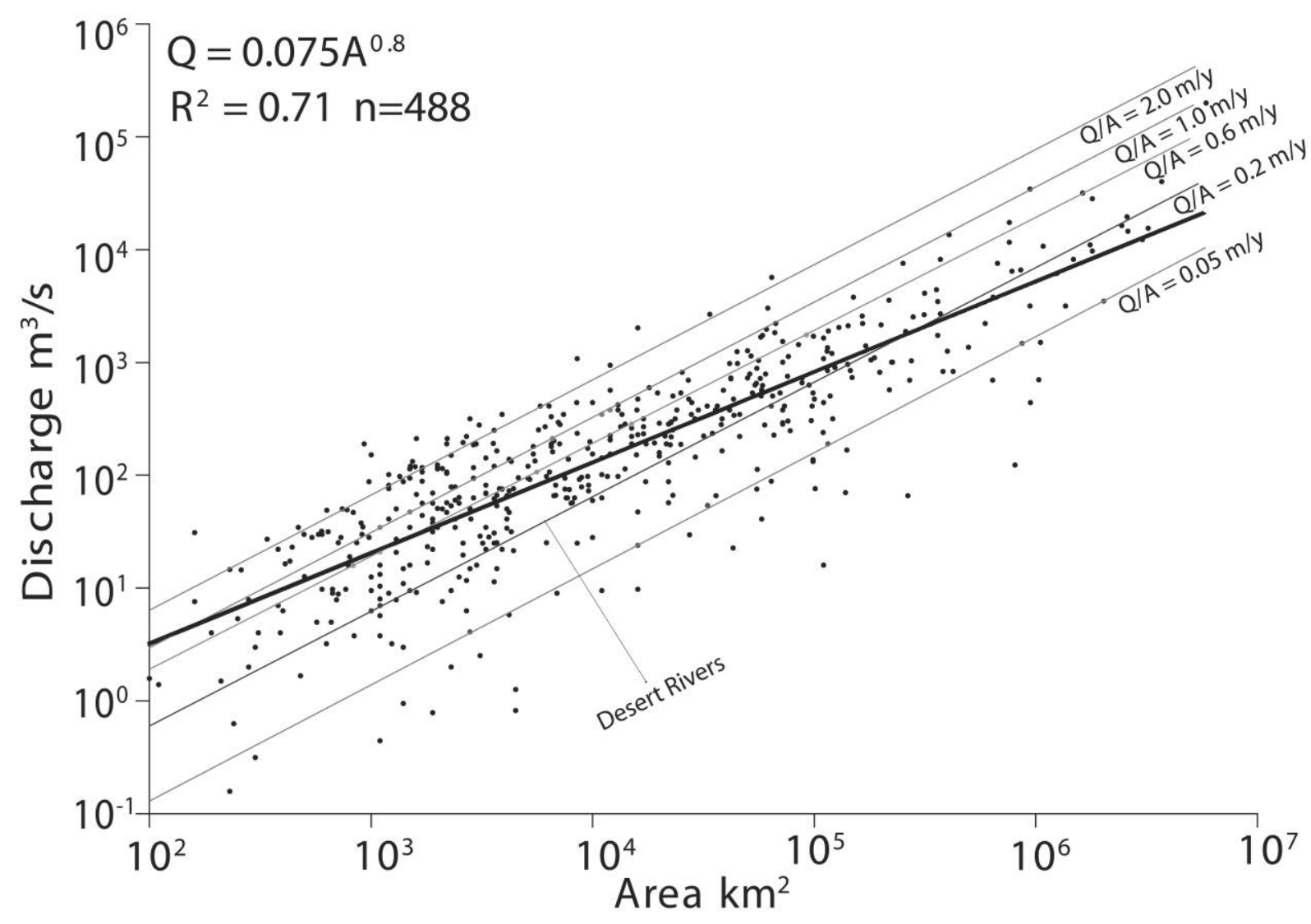

Figure 3. Basin-averaged discharge and its power-law relationship with drainage area. Superimposed are runoff $(Q /$ $A$ ) isolines that are angled to the global average relationship; these highlight the fact that due to scaling, high runoff values are limited to small- to medium-sized basins (see text for details).

database. Different reported values also reflect different methodologies: gridded databases, for example, invariably have averaged (i.e., smaller) values of topographic relief compared with those provided by a cartographic field survey. Differences related to relief, however, may soon disappear because the grid space of space shuttle radar, for example, is very high resolution $(30-90 \mathrm{~m})$, with a 1$m$ vertical resolution. Database differences may also relate to whether pre- or postreservoir values or major land disturbance values are used.

Sediment loads and water discharge values are variable (Walling and Fang 2003; Meybeck 2003), and database differences therefore also may reflect different measurement periods. This point is particularly worthy of consideration when one realizes that small rivers are more responsive to episodic events but often have been monitored for short periods of time. One such example is the Choshui River in Taiwan, whose 1962-1995 sediment load has been calculated to have been $27 \mathrm{MT} / \mathrm{yr}$; a series of large typhoons and one major earthquake between 1996 and 2001 resulted in more than 400 MT of sediment delivery (Dadson et al. 2004; Milliman and Kao 2005), increasing the Choshui longterm sediment load to $36 \mathrm{MT} / \mathrm{yr}$. Another example is the twentieth-century increase in the duration of the annual period when when the Yellow River runs dry (Wang et al. 2006). In the last few years, this trend has declined (Hui and Huang 2005). Research articles written on either side of such trends will reflect these differences in their databases (Syvitski et al. 2005a; cf. Syvitski and Saito, forthcoming).

Two databases are used in this study (table 3), both separately and in combination. The first, the $\mathrm{M} \& S 92+$ database (table A1, available in the online edition or from the Journal of Geology office), involves many of the same rivers used in the original Milliman and Syvitski (1992) study, although all of the values have been reverified and updated/corrected where possible (Syvitski 2003a). The 
M\&S92+ database comprises 294 river basins draining to coastal ocean, including most of the world's large rivers but also a significant number of small rivers. A second database (M\&F05) was kept from the original testing of the BQART model to provide a blind test of the model once the model framework was set. This second database contains 194 additional rivers and is biased toward smaller rivers since most of the large rivers were already incorporated into $\mathrm{M} \& \mathrm{~S} 92+($ table 3 ). There are 6292 river basins with areas $>100 \mathrm{~km}^{2}$ (Syvitski et al. 2005a). Thus, the two databases are small relative to the number of rivers, but they still account for $63 \%$ of the land surface draining to the global ocean and $66 \%$ of the predicted sediment load (table 3).

The databases include these parameters: (1) river name(s), (2) maximum relief, (3) 30-yr basinaveraged temperature (fig. 1), (4) discharge measured relatively near the river mouth, (5) hydrological runoff $(Q / A),(6)$ suspended sediment load $\left(Q_{s}\right),(7)$ basinwide sediment yield $\left(Q_{s} / A\right),(8)$ area of the drainage basin covered by ice $(M$. Dyurgerov, pers. comm. 2006; National Snow and Ice Data Center; and http://www.glims.org//, (9) lithology (Dürr et al., forthcoming), (10) reservoir trapping (Vörösmarty et al. 2003; Syvitski et al. $2005 a$; published literature), (11) anthropogenic erosion factor (see details below) based on population density (GPW, ver. 3; Center for International Earth Science Information Network, Columbia University, New York), and (12) the gross national product per capita (World Bank data source).

\section{Defining the $B$ Factors in the BQART Model}

Inspection of figure 4 shows that without the $B$ factors implemented, most rivers fall within a factor of 5 of the mean trend line. This suggests that

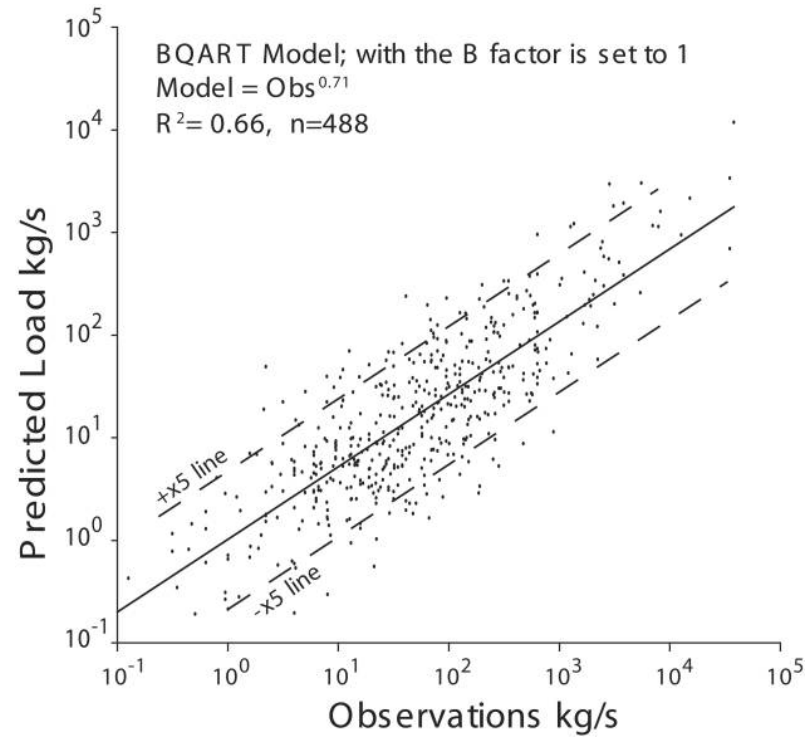

Figure 4. The BQART model predictions compared to sediment load observations from 488 globally distributed rivers, if the $B$ factor is set to 1 to eliminate the influence of glaciers, lithology, reservoir trapping, and soil erosion on predictions. The predictions are within one order of magnitude, most within a factor of 5 .

the various $B$ factors (glacial erosion, lithology, lake and reservoir trapping, and human-induced erosion) collectively should not influence sediment load much more than an order of magnitude. The literature is filled with studies highlighting the influence of these factors, but unfortunately, most studies have not normalized for the influence of relief, basin area, discharge, and temperature and thus have not isolated the influence of individual $B$ factors or established their global range. A fluvial system transitioning from ice age to modern climate conditions can experience an order of magnitude change in sediment delivery (Forbes and Syvitski

Table 2. Correlation Matrix of Terms Used in the New BQART Model

\begin{tabular}{lrrrrrrrr}
\hline & Glacier & Lithology & Trapping & Erosion & Temp & Area & Relief & Discharge \\
\hline Glacier & 1.00 & & & & & & & \\
Lithology & .10 & 1.00 & & & & & & \\
Trapping & .12 & .09 & 1.00 & & & & & \\
Soil erosion & -.04 & .25 & .17 & 1.00 & & & & \\
Basin temperature & -.30 & -.21 & -.12 & .16 & 1.00 & & & \\
Basin area & -.02 & .02 & -.03 & .01 & -.07 & 1.00 & & \\
Relief & .18 & .20 & -.08 & .12 & -.02 & .32 & 1.00 & .00 \\
Discharge & -.01 & .01 & .00 & .01 & .03 & .75 &. $\mathbf{2 5}$ & 1.00 \\
Sediment load & -.00 & .14 & .04 & .13 & .06 & $\mathbf{. 5 8}$ & $\mathbf{. 4 0}$ & $\mathbf{. 6 7}$ \\
\hline
\end{tabular}

Note. The matrix is based on observations from 488 basins (Milliman and Syvitski 1992; Milliman and Farnsworth, forthcoming; see text for details). Basin area scales strongly with discharge and less strongly with relief; discharge scales weakly with relief. Sediment load scales with discharge, area, and relief. Most of the other factors are either independent or weakly dependent on one another. Boldface denotes statistically and scientifically significant values. 
Table 3. Mean of the Main Parameters in the Two Databases Used in This Study to Deal with River Sediment Discharge

\begin{tabular}{lccc}
\hline Parameter & M\&S92+ (mean) & M\&F05 (mean) & Comments \\
\hline No. of rivers & 294 & 194 & 488 rivers \\
Area $\left(A, \mathrm{~km}^{2}\right)$ & 215,400 & 22,400 & $63 \%$ of world total \\
Relief $(R, \mathrm{~km})$ & 2.0 & 1.5 & Average $=1.8$ \\
Temperature $\left(T,{ }^{\circ} \mathrm{C}\right)$ & 12.3 & 14.2 & Average $=13.0$ \\
Runoff $(\mathrm{m} / \mathrm{yr})$ & .7 & .6 & Average $=.7$ \\
Discharge $\left(Q, \mathrm{~m}^{3} / \mathrm{s}\right)$ & 2,300 & 274 & $63 \%$ of world total \\
Sediment load $\left(Q_{\mathrm{s}}, \mathrm{MT} / \mathrm{yr}\right)$ & 8.4 & .4 & $66 \%$ of world total \\
Glacier area $\left(A_{\mathrm{g},}\right)$ & 1.0 & 1.0 & Average $=1.0$ \\
Lithology factor $(L)$ & 1.5 & 1.1 & Average $=1.3$ \\
Trapping $\left(1-T_{\mathrm{E}}\right)$ & .8 & .8 & Average $=.8$ \\
Soil erosion $\left(E_{\mathrm{h}}\right)$ & 1.3 & .1 .94 & Average $=1.2$ \\
BQART $R^{2}$ & .96 & Total $R^{2}=.95$ \\
Note. & & .94
\end{tabular}

Note. Comments provide the total value, fraction of the world total (Syvitski et al. 2005a), or the average of the two databases.

1995; Dearing and Jones 2003), but is the variance in load due to (1) changes in discharge (such as a large reduction in ice-melt discharge; Kettner and Syvitski, forthcoming), (2) warmer temperatures, (3) changes in drainage area (Overeem et al. 2005), or (4) the filter of sediment load through proglacial lakes (Kettner and Syvitski, forthcoming)? Below we discuss the four $B$ factors, suggest simple methods for their estimation, and apply the factors to improve the predictive ability of the BQART model.

Glacier Erosion Factor (I). As a basin's glacier cover increases, so does the contribution from turbid ice melt and thus sediment load (Hallet et al. 1996). Ice melt almost always carries more sediment than, for example, melting snow (Syvitski and Alcott 1995). Rivers whose hydrographs are strongly influenced by glaciers discharge a high amount of glacial flour as wash load. The grinding nature of warm-based glaciers provides additional sediment (Andrews and Syvitski 1994; Syvitski and Andrews 1994). Parks and Madison (1985) found a power-law relationship between ice cover and increasing sediment yield, whereas Guymon (1974) found a linear relationship between the two parameters. Similarly, Vizzoli (2004) found a direct relationship between glacial area and sediment production. Based on these and other studies, we propose the following algorithm to define a glacier erosion factor, $I$, as

$$
I=\left(1+0.09 A_{\mathrm{g}}\right)
$$

where $A_{\mathrm{g}}$ is the area of the drainage basin as a percentage of the total drainage area of the basin. Equation (9) allows for a range of 1 (0\% ice cover) to 10 (100\% ice cover). Hinderer (2001) provides excellent data on alpine glacial basins along with an exhaustive list of references that support equation (9) and, together with our analysis, demonstrate that Late Glacial denudation rates were an order of magnitude (or more) higher than modern denudation rates.

While a linear dependency between ice cover and erosion is simple, it does not take into account the rapid release of stored turbid meltwater during deglaciation (Kettner and Syvitski, forthcoming), the mode of glaciation (i.e., polar vs. polythermal vs. fast-flowing or surging; Elverhøi et al. 1998) the breaching of ice dams (such as jokulhlaups, or glacial outbreak floods), or the unvegetated and easily eroded paraglacial sediment cover (Forbes and Syvitski 1995; Syvitski et al. 1996). To account for these deglacial conditions, more advanced models are required (Elverhøi et al. 1998; Kettner and Syvitski, forthcoming).

Outside of the massive Greenland and Antarctic ice sheets, which are not part of this study, the global ice cover of smaller subpolar glaciers is approximately $0.8 \mathrm{M} \mathrm{km}^{2}$ or $<1 \%$ of the world's landmass draining into the ocean $\left(106 \mathrm{M} \mathrm{km}^{2}\right.$; Syvitski et al. 2005a). About $0.32 \mathrm{M} \mathrm{km}^{2}$ of ice reside in the high arctic and its archipelagos; about $0.12 \mathrm{M} \mathrm{km}^{2}$ cover the high mountains of central Asia, 0.09 M $\mathrm{km}^{2}$ cover Alaska, and another $0.036 \mathrm{M} \mathrm{km}^{2}$ cover western United States and Canada, with the remaining parts of the world (e.g., Central and South America, Africa, Middle East, Europe) accounting for the remaining $0.24 \mathrm{M} \mathrm{km}^{2}$. In the database of 488 rivers, $<10 \%$ are currently affected by an ice cover, and few rivers have $I>2$ (e.g., Klinaklini River, British Columbia; Copper River, AK). On a global basis, the Holocene impact of ice is not a large contributor of sediment erosion; however, the ice factor would have been dominant for many rivers during the Pleistocene (Forbes and Syvitski 1995; Elverhøi et al. 1998; Hinderer 2001).

Lithology Factor (L). Pinet and Souriau (1988) 
found that the erodibility of poorly consolidated versus massive rocks differs by a factor of 7 . Schaller et al. (2001) found that crystalline rocks are three times more resistant to erosion than sedimentary rocks and that the weatherability and erodibility of bedrock tend to decrease with increasing quartz content. Gaillardet et al. (1997) found a greater importance of sedimentary recycling in young orogenic belts (e.g., the Andes, with physical weathering rates of $300 \mathrm{~T} / \mathrm{km}^{2} / \mathrm{yr}$ ) compared to old cratonic shields (e.g., Guayana Shield at $13 \mathrm{~T} / \mathrm{km}^{2} /$ yr; Brazilian Shield at $11 \mathrm{~T} / \mathrm{km}^{2} / \mathrm{yr}$. These and other studies (e.g., Hinderer 2001; Dupré et al. 2003) suggest that sediment production varies with lithology within an order of magnitude. These field observations are supported by laboratory studies using the Schmidt hammer (Aydin and Basu 2005), which provides a measure of surface hardness and mechanical properties of rock material. The rebound value is the common form of measurement, and lithologies and weathering grades have values that range across an order of magnitude (Aydin and Basu 2005). Schmidt hammer results have been related to a rock's Young's modulus, uniaxial strength, and lithology (Katz et al. 2000).

In our study, we converted a global geological map (Dürr et al., forthcoming) into six broad basinaveraged lithology classes and assigned the following factors (fig. 5), based on the studies referenced above.

1. For basins composed principally of hard, acid plutonic and/or high-grade metamorphic rocks, we assigned $L=0.5$. The database contains 122 river basins, including the shield terrains from northeast Canada, Africa, Australia, Scandinavia, east South America, and India. Type basins include the Saguenay (Canada), Manzanares (Venezuela), Herbert (Australia), Congo/Zaire, and Muonio Alv (Sweden). Globally, $23 \%$ of the land surface is covered in acid plutonic rocks, Precambrian basement, or high-grade metamorphic rocks (Dürr et al., forthcoming).

2. For basins composed of mixed, mostly hard lithology, sometimes including shield material, we assigned $L=0.75$ to 18 basins. Type basins include the Columbia, Zambezi, Chao Phraya, and Yenisei. Only $5 \%$ of the global land surface is covered with these hard mixed lithologies (Dürr et al., forthcoming).

3. For basins composed of volcanic, mostly basaltic rocks (e.g., Tapti, India), or carbonate outcrops (e.g., Suwannee, United States), or mixture of hard and soft lithologies (Niger, Orinoco, Amazon), we assigned $L=1.0$ to 112 basins. Globally $17 \%$ of the earth surface is covered in volcanic and carbonate rocks (Dürr et al., forthcoming).

4. For basins characterized by a predominance of softer lithologies but having a significant area of harder lithologies, we assigned $L=1.5$ to 65 basins. Type examples include the Yukon and the Lena, with their mixture of Precambrian granites, hard carbonates, and softer siliciclastic sedimentary rocks.

5. The largest category with $165 L=2$ basins, is reserved for fluvial systems draining a significant proportion of sedimentary rocks, unconsolidated sedimentary cover, or alluvial deposits. Type basins include the Mississippi, Orange, Danube. Fully $50 \%$ of the earth surface is covered in these softer sedimentary materials (Dürr et al., forthcoming).

6. Four basins in the database are identified as having an abundance of exceptionally weak material, such as crushed rock (e.g., Waipaoa or Waiapu, New Zealand; Eel, United States) or loess deposits (e.g., Huanghe, China), and merit an $L=$ 3 designation. Only $4 \%$ of the world is covered in these highly erodable lithologies (Dürr et al., forthcoming).

The numerical range in the above lithology factors (fig. 5) has the same range as advocated by Hadley et al. (1985), Pinet and Souriau (1988), and de Vente et al. (2005) and as observed in Schmidt hammer laboratory experiments (Katz et al. 2000; Aydin and Basu 2005). The range is designed so that the global effect of lithology does not alter the main structure of the BQART model (fig. 4), that is, the global mean of $L=1$. To test whether the range should be larger, we kept the global mean of $L=$ 1 but stretched the outside classes to $L=0.1$ (for the shield rocks) and $L=10$ for the loose sedimentary rocks, with other classes adjusted accordingly. Similarly, we later compressed the $L$ range to fall between 0.75 and 1.5. In both experiments, the result reduced the predictability of the $L$ factor. When predicting the flux of sediment as would be measured at a river mouth, the range of $0.5-3$ is considered optimal.

Sediment Trapping $\left(\mathbf{1}-\mathbf{T}_{E}\right)$. Reservoirs behind dams trap approximately $26 \%$ of the global sediment delivery to the coastal ocean (Syvitski et al. 2005a), although this number appears to be steadily increasing (Liquette et al. 2004). The volume of sediment being trapped is much greater when one considers that much sediment normally would not reach the coastal zone but would be stored in alluvial fans and flood plains. For example, reservoirs on the Chinese portion of the Mekong River basin trap $30 \%$ of the flux of sediment that once passed through their location (MRC 2003; Kummu and 

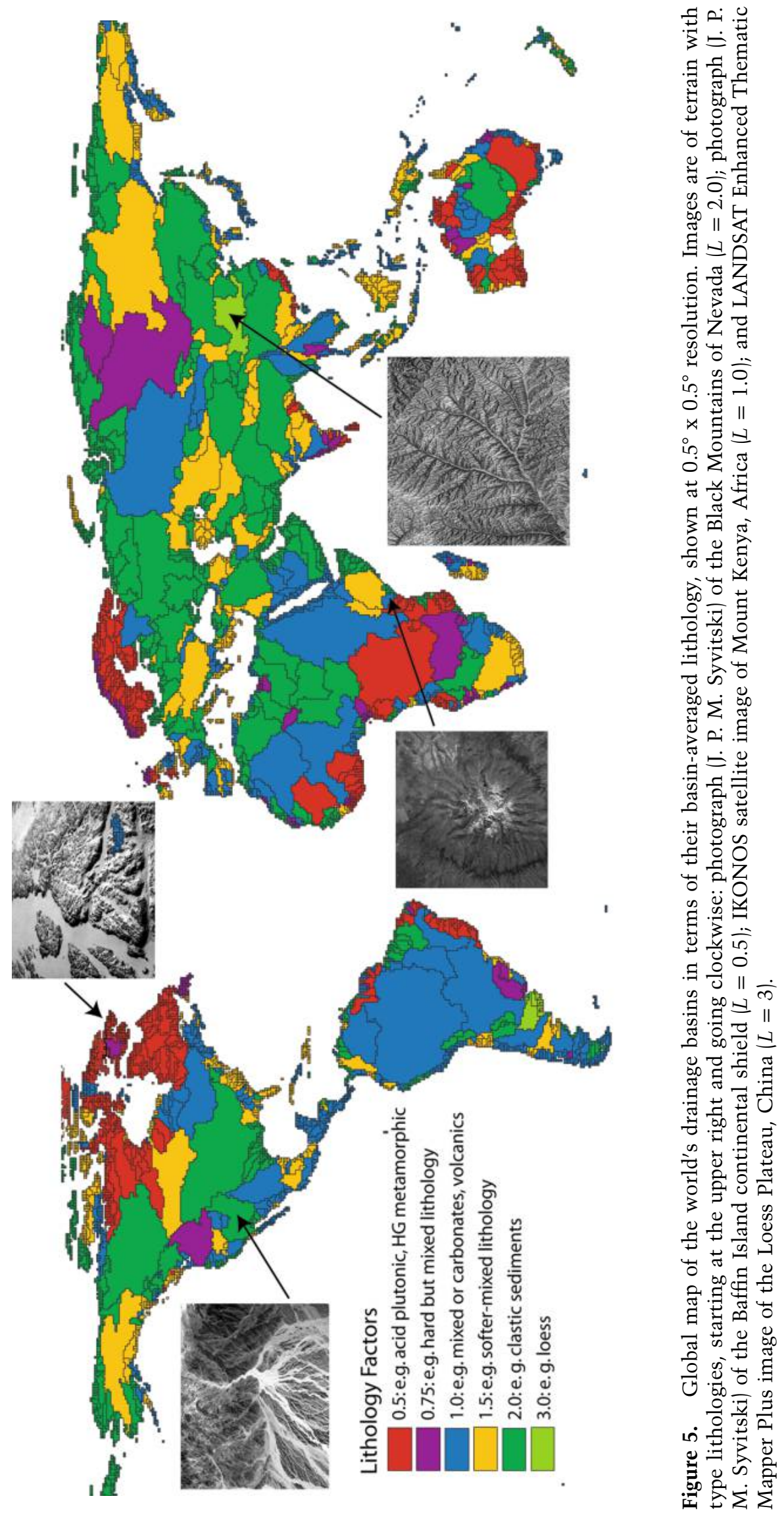

This content downloaded from 139.070.105.124 on January 22, 2020 07:37:54 AM 
Varis 2006). In the downstream Cambodian portion of the basin, the natural sediment flux has registered a reduction by only $10 \%$ (MRC 2003; Kummu and Varis 2006). As measured near the CambodiaVietnam border, the Mekong River shows no noticeable change in the delivery of sediment (MRC 2003; Kummu and Varis 2006). Trapped sediment is thus partly replenished by downstream sources, most notably by downstream bank erosion and channel deepening.

Historically, reservoirs were located along the mountainous and upland branches of the hydrologic network for the generation of hydroelectricity, in the regions where sediment production is highest (Syvitski et al. 2005a). Reservoirs are increasingly placed within flood plains as a control on seasonal flood waves and for water diversion to meet irrigation needs (fig. 6A). Both the Mississippi and Yangtze drainage basins contain more than 50,000 dams of various sizes, each reservoir affecting to some degree the conveyance of sediment to the coastal ocean (Vörösmarty et al. 2003; Xu et al. 2006; Yang et al. 2006). Dams along the Colorado, Nile, Indus, and Yellow rivers have effectively stopped sediment discharge, whereas previously these four rivers alone accounted for 10\% (1.5 BT/ yr) of sediment flux to the global ocean (fig. 6B).

A reservoir's trapping efficiency can be measured by comparing the sediment flux entering and leaving the reservoir, or retrospectively, by examining long-term trends in a river's sediment flux, normalized for discharge. A variety of formulas also can be used to calculate the trapping efficiency $\left(T_{\mathrm{E}}\right)$ of reservoirs (see Syvitski et al. 2003), most being based on residency of sediment within the reservoir. Residency time depends on the size or volume of the reservoir compared to the discharge of the river entering the reservoir. The $1-T_{\mathrm{E}}$ factor will vary between 0.1 (e.g., Guadiana, Tagus) and 1 (no sediment trapping by dams). In our combined database, 160 rivers had significant reservoirs, and 328 basins had no significant reservoirs or we used predam values of sediment load (e.g., Nile). We chose to use the predam values of a river's sediment load wherever possible; (1) our primary focus is on the geologic and geomorphic influences on a river's sediment load, and (2) a dam's trapping efficiency is variable. The vast majority of dams are expected fill in within the next 100 years, and during that period the trapping efficiency of their reservoirs will decrease. Some smaller dams release water through sluiceways to flush out the buildup of sediment; some larger dams also have some capacity for sediment flushing. The average $\left(1-T_{\mathrm{E}}\right)$ value in the database is 0.8 . The World Commission on

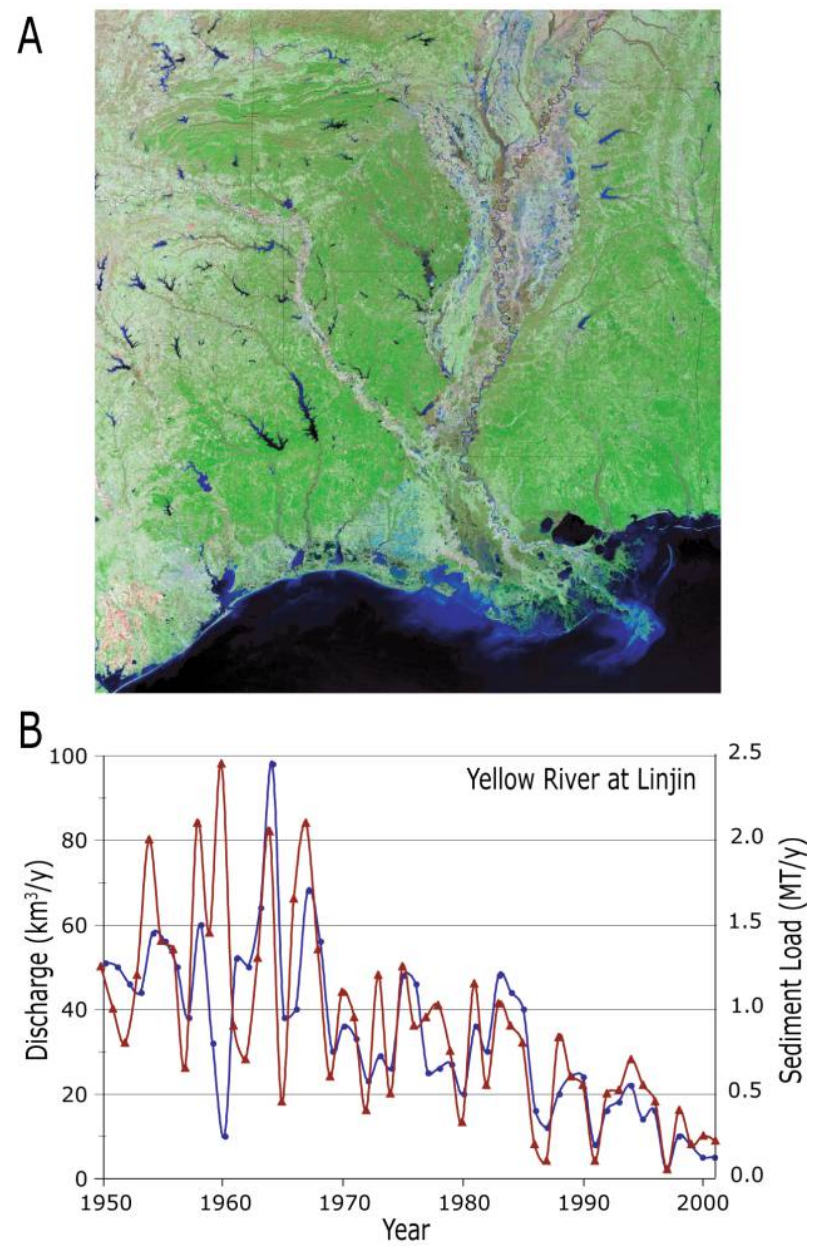

Figure 6. $A$, NASA MODIS near-infrared image (250$\mathrm{m}$ resolution) of the lower Mississippi valley, acquired January 15, 2002, at 1710 GMT, processed at the Institute of Arctic and Alpine Research Environmental Computation and Imaging Facility to accent the proliferation of lower-elevation reservoirs. $B$, Time history of the annual discharge and sediment load of the Yellow River (Huanghe) at Lijin, about $100 \mathrm{~km}$ inland from the river mouth (data source: Wang et al. 1998, with updates by J. D. Milliman). Dramatic decrease in both parameters is a result of increasing water diversion and water consumption, primarily via irrigation.

dams (http://www.dams.org// estimates the world now has 48,000 large dams (defined as higher than $15 \mathrm{~m}$ ), with an average height $31 \mathrm{~m}$ and average reservoir area of $23 \mathrm{~km}^{2}$; this is the equivalent of the construction of one large dam every day over the last 130 years. Most dams were constructed since the 1950s, and another 2000 large dams are presently under construction. Developed countries are decommissioning dams, which regionally should increase the sediment flux to the coastal 

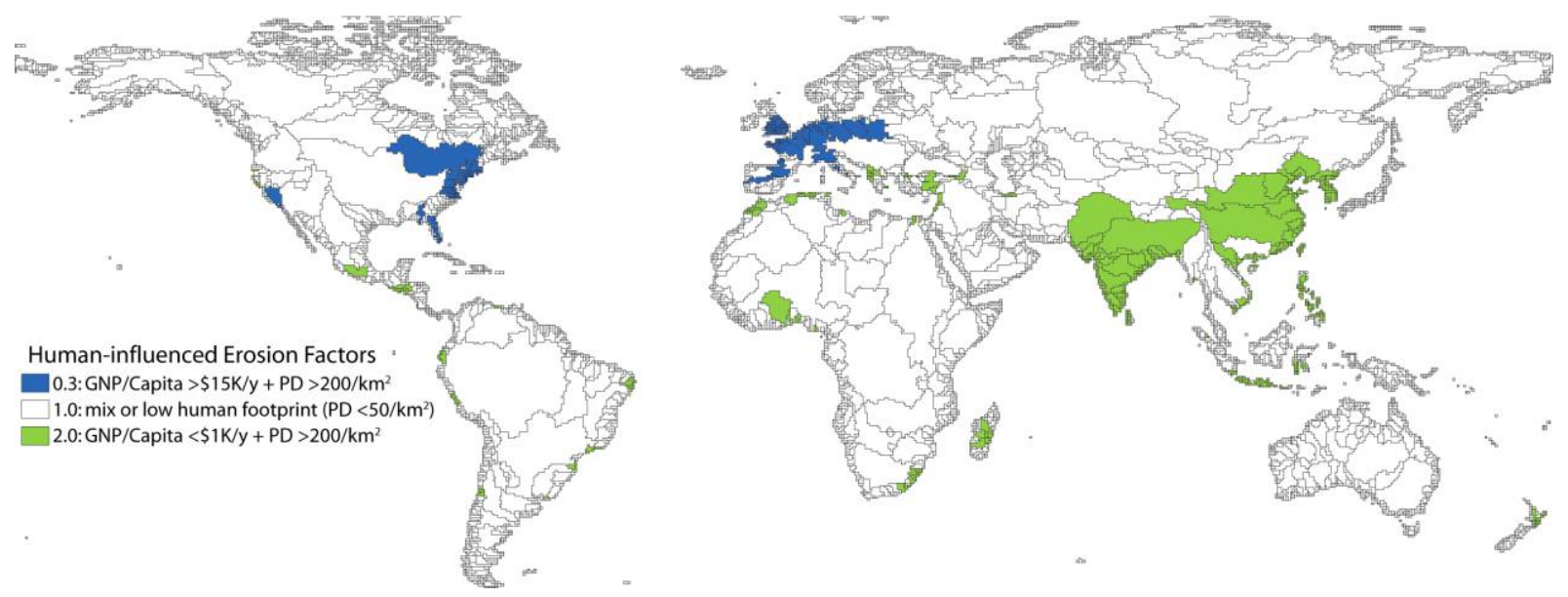

Figure 7. Global map of the world's drainage basins represented at $0.5^{\circ} \times 0.5^{\circ}$ resolution, showing human-influenced erosion factors. $E_{\mathrm{h}}=0.3$ for basins with a high-density population $(\mathrm{PD})>200 \mathrm{~km}^{2}$ and a per capita GNP $>\$ 15 \mathrm{~K} / \mathrm{yr}$; $E_{\mathrm{h}}=1$ for basins with a low human footprint $\left(\mathrm{PD}<50 \mathrm{~km}^{2}\right)$ or are a mixture of the competing influences of soil erosion and conservation; and $E_{h}=2.0$ for basins where the population is high $\left(\mathrm{PD}>200 \mathrm{~km}^{2}\right)$, but per capita GNP is low $(<\$ 1 \mathrm{~K} / \mathrm{yr})$.

ocean, but the number of decommissioned dams remains small, and in general, rivers draining developed countries (Europe, North America) have lower natural sediment yields than those draining, for example, southern Asia, Oceania, and northern South America.

Anthropogenic Factor $\left(\mathrm{E}_{h}\right)$. Humans disturb the global landscape through competing influences: urbanization, deforestation, agricultural practices, and mining activities. Selective logging, for instance, can increase a basin's sediment yield by an order of magnitude, and poor agricultural practices can increase yields even further (Douglas 1967, 1996). These changes impact smaller rivers where human activities can more easily overwhelm pristine conditions (Orpin 2004; Kasai et al. 2005). Farming on the highly erodable loess plateau in northern China increased the sediment yield of the Yellow River threefold to 10-fold since the Tong Dynasty, or 1400 yr B.P. (Milliman et al. 1987; Wang et al. 1998; Saito et al. 2001). For Japan's Takkobu watershed, catchment sediment yields increased fivefold after land use development and sevenfold with continuing agricultural development (Ahn et al. 2006). Determining the magnitude of the composite human disturbance is like trying to hit a moving target because each decade brings a new environmental situation (e.g., Restrepo and Syvitski 2006; Wang et al. 2006).

There are many algorithms used to model the influence of humans on sediment flux, such as the Soil Conservation Service curve number method
(Mishra et al. 2006), the revised universal soil loss equation (e.g., Erskine et al. 2002), and the water erosion prediction project model (Croke and Nethry 2006), among many others (de Vente 2005; Diadato, forthcoming). Unfortunately, these methods are all designed for the plot scale or, at best, small catchments and are not easily adapted to predict the $E_{\mathrm{h}}$ factor for global rivers. Recent studies point to the influence of socioeconomic conditions (e.g., Nyssen et al. 2004), land use practice (Bruijnzeel 2004), and population density (Higgitt and $\mathrm{Lu} \mathrm{2001)}$ as the overarching anthropogenic influence on sediment yield (Latrubesse et al. 2005). We therefore suggest using a simple a priori method to define the $E_{\mathrm{h}}$ factors around the world based on population density and GNP per capita (fig. 7):

Let $E_{\mathrm{h}}=0.3$ for basins with a high-density population (PD) $>200 \mathrm{~km}^{2}$ and a per capita GNP of $>\$ 15 \mathrm{~K} / \mathrm{yr}$. This category accounts for 50 rivers within the database, principally from western Europe and the eastern United States, that are well regulated and contained by stop-banks hardened by raft and concrete (e.g., Pamlico, Adour, Avon, Oder, Rhine; fig. 7).

Let $E_{\mathrm{h}}=1$ for basins with a low human footprint $\left(\mathrm{PD}<50 \mathrm{~km}^{2}\right)$ or those containing a mixture of the competing influences of soil erosion and conservation (e.g., Amazon, Lena, Orange; fig. 7); this category dominates the world and represents 339 rivers in the database.

Let $E_{\mathrm{h}}=2.0$ for basins where the population is high (PD $\left.>200 \mathrm{~km}^{2}\right)$, but per capita GNP is low 
$(\leq \$ 1 \mathrm{~K} / \mathrm{yr})$. This category includes 97 basins in the database, primarily located in Asia, central Asia, and parts of Africa, and populated areas in the Philippines and Indonesia (e.g., Wu, Krishna, Lanyang, Liao, Yangtze; fig. 7). Historically, these basins have not received the resources to engineer solutions to problems of soil erosion (at least when the observations were made), or they represent areas where deforestation is near its historical peak, farming practices are poor, or open-pit mining is intense.

Other workers (e.g., Nyssen et al. 2004; Latrubesse et al. 2005) have observed the numerical range in $E_{\mathrm{h}}$ values, but the potential range is still much smaller than what is associated with human disturbance at the plot scale (Bruijnzeel 2004). In this sense, small rivers basins may exceed values of $E_{\mathrm{h}}=2.0$. We also recognize the use of population density and per capita GNP as a very broad-brush, albeit a priori, approach or global response to these economic and human perturbations will be unequal. For example, portions of New Zealand have a low human population density but a high sheep population. As such, sheep grazing following deforestation has led the Waipaoa and Waiapu basins to have much higher $E_{\mathrm{h}}$ values (Hicks et al. 2000), and a value of $E_{\mathrm{h}}=8$ has been suggested for these very small rivers (Kettner et al. 2005).

Based on the work of Schumm and Rea (1995), we also recognize $E_{\mathrm{h}}$ to be time dependent. After an initial disturbance, such as deforestation, the pulse of increased sediment yield may return to a predisturbance sediment supply if the disturbance is not sustained; an exponential decay function has been suggested (Higgitt and Lu 2001) to describe this. However, the global diversity of this pattern is likely to be high. For example, road construction, urbanization, and farming in highly erodable terrain have led to a ca. 3.5-fold increase in long-term sediment discharge from the Lanyang River in northeast Taiwan (Kao and Liu 2002). The Lanyang River's load has not returned to ambient conditions; rather, the rate of erosion has gradually increased after each major short-lived disturbance (fig. 8). Another problem in quantifying the anthropogenic $E_{\mathrm{h}}$ parameter is determining the extent to which humans might be responsible for creating conditions for soil erosion during some natural event such as a typhoon (fig. 8).

\section{Testing the BQART Model}

With the $B$ schema set, we can apply the BQART model to 294 rivers that formed the $M \& S 92+$ database. BQART could account for $96 \%$ of the variance in the original observations, with a bias of
$7 \%$ (fig. 9A). In a blind application of BQART to the M\&F05 database of an additional 194 rivers, the model captured $95 \%$ of the data variance, with a $5 \%$ bias (fig. 9A). When applied to the combined database of 488 rivers, the BQART model showed no ensemble over- or underprediction, had a bias of just $3 \%$ across six orders of magnitude in observational values, and accounted for $96 \%$ of the data variance (table 3; fig. 9A). This is a vast improvement over the ART model (fig. 2), which accounts for just $57 \%$ of the database variance.

The various parameters used in the BQART model can be implemented sequentially to understand how these parameters influence a river's sediment flux. The combined database of 488 rivers covers $63 \%$ of the land surface draining to the coastal ocean (table 3 ), and we reason that rivers outside of the database would not operate differently, as the geographical range of the 488 rivers is highly representative of global geology, climate, and socioeconomic conditions. When employing just the tectonic factors of drainage area and relief, this reduced model determines $57 \%$ of the between-river variability in sediment load. When adding the ice cover factor to this tectonic model, data variance is not reduced further (i.e., most of the rivers in the database are not affected by glaciers); however, the factor remains valuable when applying the BQART model to glaciated terrain or to geological periods when glaciation played a more prominent global role. When adding lithology to the tectonic parameters, we improve the predictability of sediment load for the 488 rivers by $8 \%$. Based strictly on these geological parameters (basin area, relief, lithology, ice erosion), $65 \%$ of the between-river sediment load is explained.

When climate factors are sequentially added to the geological parameters, discharge accounts for an additional $3 \%$ and basin temperature accounts for an additional $10 \%$ of the between-river load. Together the climatic factors reinforce each other to account for an additional $14 \%$ of the variability in global patterns in load. Since there is a strong correlation between discharge and area (fig. 6B; table 2), and basin area is part of the above geological parameters, the influence of discharge has the false appearance of being less important. Using just geologic and geographic influences $(I, L, Q, A, R, T)$, this GEO model accounts for $79 \%$ of the betweenriver load, even though the comparison is made to a database of load values already strongly influenced by humans (fig. 9B). Not unexpectedly, those rivers that have neutral anthropogenic factors $\left(T_{\mathrm{E}}\right.$, $E_{\mathrm{h}}$ ), are well predicted (fig. $9 B$ ).

When added to the above GEO model (fig. 9B), 


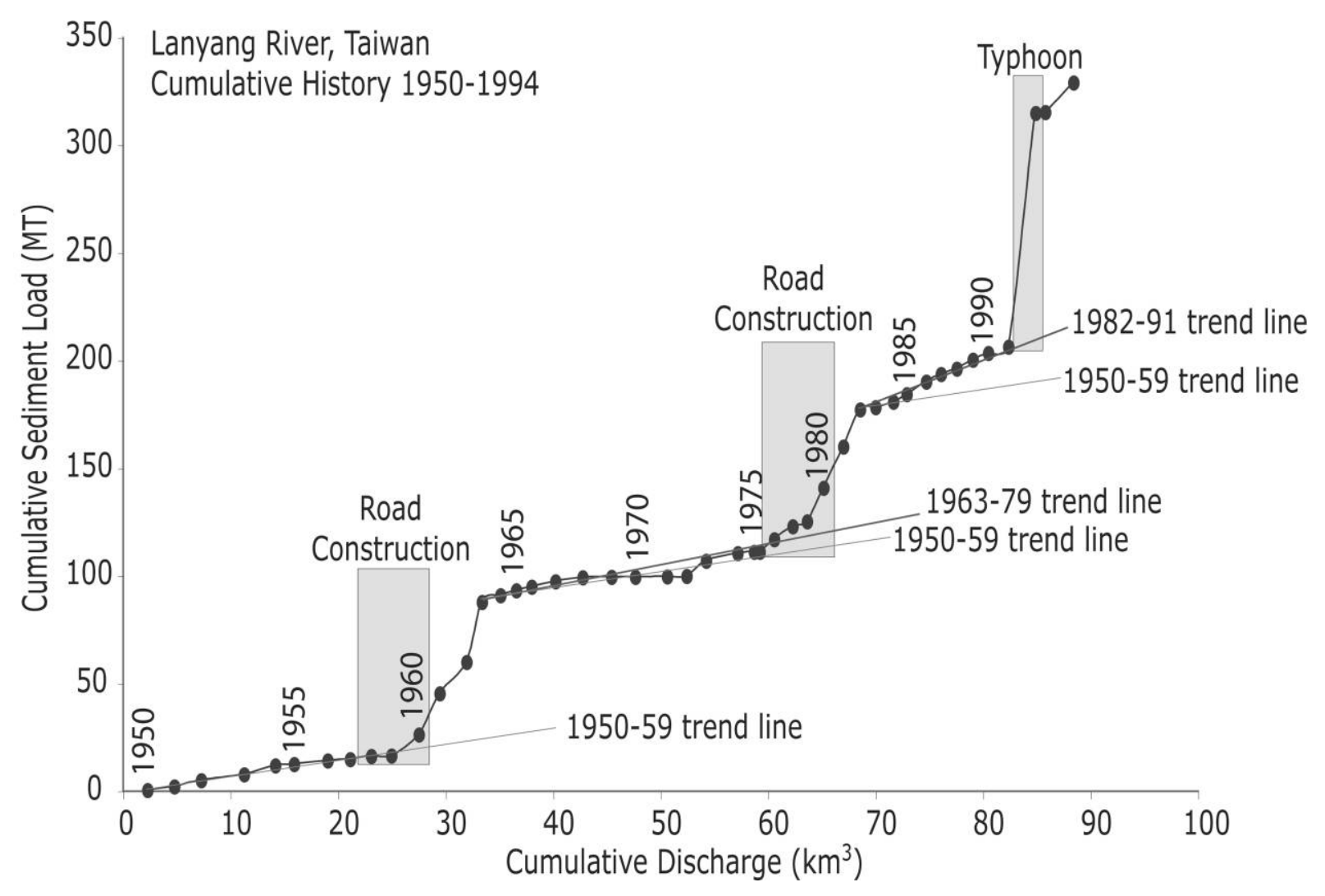

Figure 8. "Walling" diagram shows the cumulative sediment load of the Lanyang River $\left(\right.$ basin area $\left.=890 \mathrm{~km}^{2}\right)$, northeast Taiwan, as a function of cumulative discharge across 44 years (data source: Syvitski et al. 2005c). Three background trend lines are separated by marked intervals of unusually high sediment loads that reflect disturbances associated with road construction, increased farming activity, or a typhoon. After each disturbance, the background trend line shows an increase in the rate of sediment transported to the coast.

reservoir trapping explains another $9 \%$ of the between-river load. Because many load values in the database represent prereservoir conditions, the impact of reservoir trapping would increase substantially when compared to current conditions (Syvitski et al. 2005a). The impact of anthropogenic erosion explains another $9 \%$ of the between-river loads in the database. Taken together, the human effects account for $16 \%$ of the between-river loads. Regionally, the human factors can range far wider, with European, African, and North American rivers transporting far less sediment than before the impact of humans (at $-26 \%,-39 \%$, and $-19 \%$, respectively; Syvitski et al. 2005a) and with Indonesia and Oceania transporting far more sediment (at $81 \%$ and $100 \%$, respectively; Syvitski et al. 2005a).

\section{A Word on Sediment Yield}

Sediment yield $\left(Y_{\mathrm{s}}\right)$ is the transport load normalized per unit drainage basin area, in dimensions of $M /$
$\mathrm{L}^{2} / \mathrm{T}$, and can include both solid and dissolved loads (for a thorough discussion, see Syvitski 2003b). The term holds special importance to geomorphologists, who employ observations on yield in their study on denudation, that is, the measure of earth surface removal with respect to a datum. By simply dividing the BQART equations by basin area, it is possible to convert the load equations into catchment yield for suspended particulate matter:

$$
Y_{\mathrm{s}}=\omega B Q^{0.31} A^{-0.5} R T \text {. }
$$

When compared with observed detrital yields, the converted BQART yield equations offer the same level of prediction $\left(R^{2}=0.94\right)$ for the 488 globally distributed rivers (fig. 10).

\section{Geology, Geography, and Humans}

The BQART model provides a mechanism to quantify the influences that control sediment flux to the 

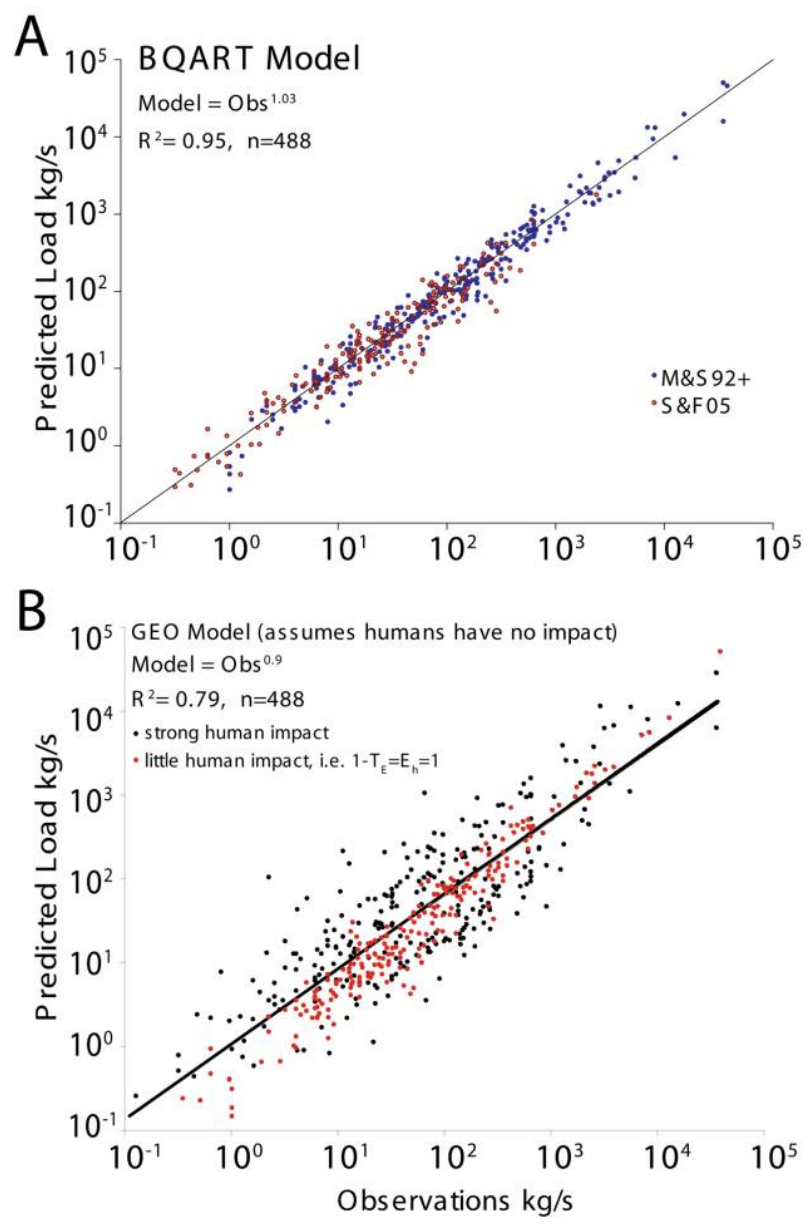

Figure 9. $A$, The BQART model captures $96 \%$ of the data variance when compared to observations from 294 globally distributed rivers (M\&S92+ data points), with a $7 \%$ bias. In a blind test on another 194 globally distributed rivers (M\&F05 data points), the BQART model captures $93 \%$ of the data variance with a $5 \%$ bias. The BQART model shows a $3 \%$ bias when applied to the combined database of 488 rivers and accounts for $95 \%$ of the data variance. $B$, In an application of the BQART model where human influences are not taken into account (discounting reservoir trapping and soil erosion), and when compared to observations that contain the impact of humans, the GEO model globally captures $79 \%$ of the data variance, with a $10 \%$ bias. Those rivers that show little impact by humans are well predicted.

coastal zone. Compared to the original ART model, the BQART model remains heavily influenced by tectonics through basin area and relief, expands the influence of climate by adding discharge to the temperature factor, adds geology through lithology and glacier erosion, and, importantly, adds human influences through the trapping efficiency of reservoirs and human disturbance of the landscape.
By their very size, large basins contain a range of lithologies, thereby integrating erodable and resistant rocks. Smaller basins, in contrast, are likely to be influenced by a narrow range in lithology. Future research should expand on our defined lithology influence and include the impact of fracture density, through global maps of rock strain.

The importance of ice as an agent of erosion is well established. A survey of sediment volumes indicates that fjords conservatively hold $25 \%$ of the world's delivery of sediment by rivers, over the last 100-kyr cycle (Syvitski and Shaw 1995), in large part because of late Pleistocene glaciation and the resulting delivery of huge volumes of sediment to fjord basins. While the sediment supply to many fjords has been greatly reduced during the Holocene, sediment flux into fjords remains enormous in the deglaciating environments of Alaska, Svalbard, and Greenland (Syvitski and Shaw 1995).

The BQART model allows the role of geography to be quantified through a basin's location and its effect on climate. Holding all geologic parameters constant (area, relief, lithology), a dry arctic river can convey 100 times less sediment to the sea than a river in a wet tropical basin. The BQART model thereby provides a powerful tool for paleoceanographers who view continental margins as the taperecorder of earth's history. By ascertaining sediment volumes per climate interval and knowing basin properties, it should be possible to invert for climate changes with this new model. Given the strong influence of humans on a river's sediment

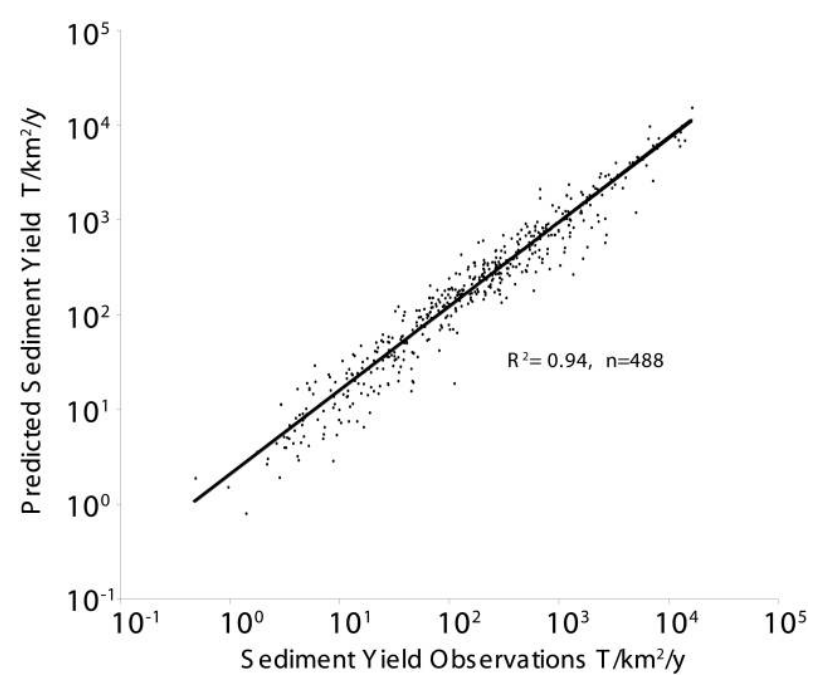

Figure 10. Sediment yield predictions using the BQART model provide the same level of accuracy as BQART predictions of sediment load (cf. fig. 9A). 
load, we caution use of current observational data, even from the recent past.

While it is possible to determine human influences on a river-by-river basis (e.g., fig. 8), to understand the globally varied socioeconomic impacts of humans on soil erosion or reservoir trapping requires up-to-date information on global sediment loads and the ability to recover from historical influences. It is truly unfortunate that highquality observational data on fluvial sediment loads are largely no longer collected, particularly when earth is undergoing such dramatic surface dynamic changes.

The BQART model determines the delivery rate of sediment for a river measured at or near sea level. The model does not provide within-basin details on sediment erosion and transport, or information on sediment retention in floodplain, deltas, and estuaries. A complete global source-to-sink surface dynamic model remains to be constructed and tested.

\section{A C K N O W LED G M EN T S}

The study has been supported by a large number of colleagues: K. Farnsworth, C. Vörösmarty, A. Kettner, Y. Saito, D. Walling, M. Meybeck, B. Meade, and T. Mulder, to name but a few. The study forms a contribution to the Scientific Committee on Oceanic Research/Land-Ocean Interactions in the Coastal Zone working group on Sediment Retention in Estuaries. The work has been supported by the Coastal Geosciences program of the U.S. Navy Office of Naval Research, by NASA (IDS/ NNG04GH75H), and by the National Science Foundation (OPP-HARC). We thank Jon Warrick (USGS) and an anonymous reviewer for their valuable comments on an earlier draft of this article.

\section{R E F E R E N C E S C I T E D}

Ahn, Y. S.; Mizugaki, S.; Nakamura, F.; and Nakamura, Y. 2006. Historical change in lake sedimentation in Lake Takkobu, Kushiro Mire, northern Japan over the last 300 years. Geomorphology 78:321-334.

Ahnert, F. 1970. Functional relationships between denudation, relief, and uplift in large mid-latitude drainage basins. Am. I. Sci. 268:243-263.

Anderson, R. S. 1994. Evolution of the Santa Cruz Mountains, California, through tectonic growth and geomorphic decay. I. Geophys. Res. 99:20,161-20,179.

Andrews, J. T., and Syvitski, J. P. M. 1994. Sediment fluxes along high latitude glaciated continental margins: northeast Canada and eastern Greenland. In Hay, W., ed. Global sedimentary geofluxes. Washington, DC, National Academy of Sciences Press, p. 99-115.

Aydin, A., and Basu, A. 2005. The Schmidt hammer in rock material characterization. Eng. Geol. 81:1-14.

Berne, S.; Rabineau, M.; Flores, J. A.; and Sierro, F. J. 2004. The impact of quaternary global change on strata formation: exploration of the shelf edge in the northwest Mediterranean Sea. Oceanography 17:92-103.

Boulton, G. S. 1990. Sedimentary and sea level changes during glacial cycles and their control on glacimarine facies architecture. In Dowdeswell, J. A., and Scorse, J. D., eds. Glaciomarine environments: processes and sediments. Geol. Soc. Spec. Publ. 53, p. 15-52.

Bruijnzeel, L. A. 2004. Hydrological functions of tropical forests: not seeing the soil for the trees? Agric. Ecosyst. Environ. 104:185-228.

Croke, J., and Nethery, M. 2006. Modeling runoff and soil erosion in logged forests: scope and application of some existing models. Catena 67:35-49.

Dadson, S. J.; Hovius, N.; Chen, H.; Dade, W. B.; Lin, J.C.; Hsu, M.-L.; Lin, C.-W.; et al. 2004. Earthquake- triggered increase in sediment delivery from an active mountain belt. Geology 32:733-736.

Dearing, J. A., and Jones, R. T. 2003. Coupling temporal and spatial dimensions of global sediment flux through lake and marine sediment records. Global Planet. Change 39:147-168.

de Vente, J.; Poesen, J.; and Verstraeten, G. 2005. The application of semi-quantitative methods and reservoir sedimentation rates for the prediction of basin sediment yield in Spain. I. Hydrol. 305:63-86.

Diodato, N. 2006. Modeling net erosion responses to enviroclimatic changes recorded upon multisecular timescales. Geomorphology 80:164-177.

Douglas, I. 1967. Man, vegetation and the sediment yield of rivers. Nature 215:925-928.

1996. The impact of land-use changes, especially logging, shifting cultivation, mining and urbanization on sediment yields in humid tropical Southeast Asia: a review with special reference to Borneo. Int. Assoc. Hydrol. Sci. Publ. 236:473-482.

Dupré, B.; Dessert, C.; Oliva, P.; Goddéris; Y.; Viers; J.; François, L.; Millot, R.; and Gaillardet, J. 2003. Rivers, chemical weathering and Earth's climate. C. R. Geosci. 335:1141-1160.

Dürr, H. H.; Meybeck, M.; and Dürr, S. H. Forthcoming. Lithologic composition of the Earth's continental surfaces derived from a new digital map emphasizing riverine material transfer. Global Planet. Change.

Elverhøi, A.; Hooke, R. L.; and Solheim, A. 1998. Late Cenozoic erosion and sediment yield from the Svalbard-Barents sea region: implications for understanding erosion of glacierized basins. Quat. Sci. Rev. 17: 209-241.

Erskine, W. D.; Mahmoudzadeh, A.; and Myers, C. 2002. Land use effects on sediment yields and soil loss rates 
in small basins of Triassic sandstone near Sydney, NSW, Australia. Catena 49:271-287.

Forbes, D., and Syvitski, J. P. M. 1995. Paraglacial coasts. In Woodruffe, C., and Carter, R. W. G., eds. Coastal evolution. Cambridge, Cambridge University Press, p. 373-424.

Fournier, F. 1949. Les factuers climatiques de l'erosion du sol. Assoc. Geog. Fr. Bull. 203:97-103.

- 1960. Climat et erosion. Paris, Presses Universitaires de France, $201 \mathrm{p}$.

Gaillardet, J.; Dupré, B.; Allegre, C. J.; and Negre, P. 1997. Chemical and physical denudation in the Amazon River Basin. Chem. Geol. 142:141-173.

Gaillardet, J.; Dupré, B.; Louvat, P.; and Allegre, C. J. 1999. Global silicate weathering and $\mathrm{CO}_{2}$ consumption rates deduced from the chemistry of large rivers. Chem. Geol. 159:3-30.

Guymon, G. L. 1974. Regional sediment analysis of Alaska streams. J. Hydraul. Div. Am. Soc. Civ. Eng. 100:41-51.

Hadley, R. F.; Lal, R.; Onstand, C. A.; Walling, D. E.; and Yair, A. 1985. Recent developments in erosion and sediment yield studies. Paris, International Hydrological Programme, UNESCO.

Hallet, B.; Hunter, L.; and Bogen, J. 1996. Rates of erosion and sediment evacuation by glaciers: a review of field data and their implications. Global Planet. Change 12: 213-235.

Harrison, C. G. 1994. Rates of continental erosion and mountain building. Geol. Rundsch. 83:431-447.

Hay, W. W. 1994. Pleistocene-Holocene fluxes are not the earth's norm. In Hay, W. W., ed. Global sedimentary geofluxes. Washington, DC, National Academy of Sciences Press, p. 15-27.

Hay, W. W.; Rosol, M. J.; Jory, D. E.; and Sloan, J. L., II. 1987. Tectonic control of global patterns and detrital and carbonate sedimentation. In Doyle, L. J., and Roberts, H. H., eds. Carbonate-clastic transitions. Vol. 42. Developments in sedimentology. Amsterdam, Elsevier, p. 1-34.

Hay, W. W., and Southam, J. R. 1977. Modulation of marine sedimentation by the continental shelves. In Andersen, N. R., and Malahoff, A., eds. The fate of fossil fuel $\mathrm{CO}_{2}$ in the ocean. New York, Plenum, p. 569604.

Heusch, B., and Millies-Lacroix, A. 1971. Une methode pour estimer l'ecoulement et l'erosion dans un bassin: application au Maghreb. Mines Geol. (Rabat) 33:2139.

Hicks, D. M.; Gomez, B.; and Trustrum, N. A. 2000. Erosion thresholds and suspended sediment yields: Waipaoa River Basin, New Zealand. Water Resour. Res. 36:1129-1142.

Hicks, D. M.; Hill, J.; and Shankar, U. 1996. Variation of suspended sediment yields around New Zealand: the relative importance of rainfall and geology. Int. Assoc. Hydrol. Sci. Publ. 236:149-156.

Higgitt, D. L., and Lu, X. X. 2001. Sediment delivery to the Three Gorges. I. Catchment controls. Geomorphology 41:143-156.
Hinderer, M. 2001. Late Quaternary denudation of the Alps, valley and lake fillings and modern river loads. Geodin. Acta 14:231-263.

Holeman, J. N. 1968. The sediment yield of major rivers of the world. Water Resour. Res. 4:737-747.

Holland, H. D. 1981. River transport to the oceans. In Emiliani, C., ed. The ocean lithosphere. Vol. 7. The sea. New York, Wiley, p. 763-800.

Hui, F., and Huang, H. 2005. Changes in Huanghe (Yellow) River estuary since artificial re-routing in 1996. Chin. I. Oceanol. Limnol. 23:299-305.

Inman, D. L., and Jenkins, S. A. 1999. Climate change and the episodicity of sediment flux of small California rivers. I. Geol. 107:251-270.

Jansen, J. M., and Painter, R. B. 1974. Predicting sediment yield from climate and topography. I. Hydrol. 21:371380.

Kao, S. J., and Liu, K. K. 2002. Exacerbation of erosion induced by human perturbation in a typical Oceania watershed: insight from 45 years of hydrological records from the Lanyang-Hsiu River, northeastern Taiwan. Global Biogeochem. Cycles, vol. 16. doi:10.1029/ 2000 GB001334.

Kapsimalis, V.; Pavlakis, P.; Poulos, S. E.; Alexandri, S.; Tziavos, C.; Sioulas, A.; Filippas, D.; and Lykousis, V. 2005. Internal structure and evolution of the late Quaternary sequence in a shallow embayment: the Amvrakikos Gulf, NW Greece. Mar. Geol. 222:399-418.

Kasai, M.; Brierley, G. J.; Page, M. J.; Marutani, T.; and Trustrum, N. A. 2005. Impacts of land use change on patterns of sediment flux in Weraamaia catchment, New Zealand. Catena 64:27-60.

Katz, O.; Rechesa, Z.; and Roegiers, J.-C. 2000. Evaluation of mechanical rock properties using a Schmidt hammer. Int. I. Rock Mech. Mining Sci. 37:723-728.

Kettner, A. J., and Syvitski, J. P. M. Forthcoming. Predicting discharge and sediment flux of the Po River, Italy since the Late Glacial Maximum. Int. Assoc. Sedimentol. Spec. Publ.

Kettner, A. J.; Syvitski, J. P. M.; and Gomez, B. 2005. Simulating the effects of natural events and anthropogenic activity on sediment discharge to the Poverty Shelf of New Zealand during the late Holocene. EOS: Trans. Am. Geophys. Union 86, Abstr. H51C-0388.

Kummu, M., and Varis, O. 2006. Sediment-related impacts due to upstream reservoir trapping in the Lower Mekong River. Geomorphology, doi:10.1016/ j.geomorph.2006.03.024.

Latrubesse, E. M.; Stevaux, J. C.; and Sinha, R. 2005. Tropical rivers. Geomorphology 70:187-206.

Langbein, W. B., and Schumm, S. A. 1958. Yield of sediment in relation to mean annual precipitation. Trans. Am. Geophys. Union 39:1076-1084.

Liquette, C.; Canals, M.; Arnau, P.; Urgeles, R.; and Durrier de Madron, X. 2004. The impact of humans on strata formation along Mediterranean margins. Oceanography 17:42-51.

Liu, J. P.; Milliman, J. D.; Gao, S.; and Cheng, P. 2004. Holocene development of the Yellow River's sub- 
aqueous delta, north Yellow Sea. Mar. Geol. 209:4567.

Ludwig, W., and Probst, J.-L. 1998. River sediment discharge to the ocean: present-day controls and global budgets. Am. I. Sci. 298:265-295.

Meybeck, M. 2003. Global analysis of river systems: from Earth system controls to Anthropocene syndromes. Philos. Trans. R. Soc. B 358:1935-1955.

Meybeck, M.; Laroche, L.; Darr, H. H.; and Syvitski, J. P. M. 2003. Global variability of total suspended solids and their fluxes in rivers. Global Planet. Change 39: 65-93.

Milliman, J. D. 1980. Transfer of river-borne particulate material to the oceans. In Martin, J.; Burton, J. D.; and Eisma, D., eds. River inputs to ocean systems. SCOR/ UNEP/UNESCO Review and Workshop. Rome, Food and Agriculture Organization of the United Nations, p. $5-12$.

Milliman, J. D., and Farnsworth, K. L. Forthcoming. River runoff, erosion and delivery to the coastal ocean: a global analysis. Cambridge University Press.

Milliman, J. D., and Kao, S.-J. 2005. Hyperpycnal discharge of fluvial sediment to the ocean: impact of Super-Typhoon Herb (1996) on Taiwanese rivers. I. Geol. 113:503-516.

Milliman, J. D., and Meade, R. H. 1983. Worldwide delivery of river sediment to the oceans. I. Geol. 91:121.

Milliman, J. D.; Qin, Y. S.; Ren, M. E.; and Saito, Y. 1987. Man's influence on the erosion and transport of sediment by Asian rivers: the Yellow River (Huanghe) example. I. Geol. 100:751-762.

Milliman, J. D., and Syvitski, J. P. M. 1992. Geomorphic/ tectonic control of sediment discharge to the ocean: the importance of small mountainous rivers. I. Geol. 100:525-544.

Millot, R.; Gaillardet J.; Dupre, B.; and Allegre, C. J. 2003. Northern latitude chemical weathering rates: clues from the Mackenzie River Basin, Canada. Geochim. Cosmochim. Acta 67:1305-1329.

Mishra, S. K.; Tyagi, J. V.; Singh, V. P.; and Singh, R. 2006. SCS-CN-based modeling of sediment yield. I. Hydrol. 324:301-322.

Molnar, P. 2001. Climate change, flooding in arid environments, and erosion rates. Geology 29:1071-1074.

—. 2004. Late Cenozoic increase in accumulation rates of terrestrial sediment: how might climate change have affected erosion rates? Annu. Rev. Earth Planet. Sci. 32:67-89.

Morehead, M.; Syvitski, J. P.; and Hutton, E. W. H. 2001. The link between abrupt climate change and basin stratigraphy: a numerical approach. Global Planet. Sci. 28:107-127.

MRC (Mekong River Commission). 2003. State of the basin report. Phnom Penh, Mekong River Commission, $300 \mathrm{p}$.

Mulder, T., and Syvitski, J. P. M. 1996. Climatic and morphologic relationships of rivers: implications of sea level fluctuations on river loads. I. Geol. 104:509-523.
Nittrouer, C. A. 1999. The formation of continental margin strata. Mar. Geol. 154:1-420.

Nyssen, J.; Poesen, J.; Moeyersons, J.; Deckers, J.; Haile, M.; and Lang, A. 2004. Human impact on the environment in the Ethiopian and Eritrean highlands-a state of the art. Earth Sci. Rev. 64:273-320.

Orpin, A. R. 2004. Holocene sediment deposition on the Poverty-slope margin by the muddy Waipaoa River, east coast New Zealand. Mar. Geol. 209:69-90.

Overeem, I.; Syvitski, J. P. M.; Hutton, E. W. H.; and Kettner, A. J. 2005. Stratigraphic variability due to uncertainty in model boundary conditions: a case study of the New Jersey Shelf over the last 21,000 years. Mar. Geol. 224:23-41.

Parks, B., and Madison, R. J. 1985. Estimation of selected flow and water quality characteristics of Alaskan Streams. USGS Water Res. Investig. Rep. 84-4247.

Pinet, P., and Souriau, M. 1988. Continental erosion and large-scale relief. Tectonics 7:563-582.

Restrepo, J. D., and Syvitski, J. P. M. 2006. Assessing the effect of natural controls and land use change on sediment yield in a major Andean river: the Magdalena drainage basin, Colombia. Ambio 35:65-74.

Saito, Y.; Yang, Z.; and Hori, K. 2001. The Huanghe (Yellow River) and Changjiang (Yangtze River) deltas: a review of their characteristics, evolutions and sediment discharge during the Holocene. Geomorphology 41:219-231.

Schaller, M.; von Blanckenburg, F.; Hovius, N.; and Kubik, P. W. 2001. Large-scale erosion rates from in situproduced cosmogenic nuclides in European river sediments. Earth Planet. Sci. Lett. 188:441-458.

Schumm, S. A. 1965. Quaternary paleohydrology. In Wright, H. E., Jr., and Frey, D. G, eds. The Quaternary of the United States. Princeton, NJ, Princeton University Press, p. 783-794.

Schumm, S. A., and Hadley, R. F. 1961. Progress in the application of landform analysis in studies of semiarid erosion. Washington DC, USGS Circular 437, 14 p.

Schumm, S. A., and Rea, D. K. 1995. Sediment yield from disturbed earth systems. Geology 23:391-394.

Small, E. E., and Anderson, R. S. 1995. Geomorphically driven late Cenozoic rock uplift in the Sierra Nevada, California. Science 270:277-280.

Syvitski, J. P. M. 2002. Sediment transport variability in arctic rivers: implications for a warmer future. Polar Res. 21:323-330.

- 2003a. The influence of climate on the flux of sediment to the coastal ocean. Proceedings of OCEANS 2003, San Diego. Marine Technology Society/Institute of Electrical and Electronics Engineers, Holland, p. 496-502.

- 2003b. Sediment fluxes and rates of sedimentation. In Middleton, G. V., ed. Encyclopedia of sediments and sedimentary rocks. Dordrecht, Kluwer Academic, p. 600-606.

- 2003c. Supply and flux of sediment along hydrological pathways: research for the 21 st century. Global Planet. Change 39:1-11.

Syvitski, J. P. M., and Alcott, J. M. 1995. RIVER3: sim- 
ulation of water and sediment river discharge from climate and drainage basin variables. Comput. Geosci. 21:89-151.

Syvitski, J. P. M., and Andrews, J. T. 1994. Climate change: numerical modelling of sedimentation and coastal processes, eastern Canadian arctic. Arct. Alp. Res. 26:199-212.

Syvitski, J. P. M.; Harvey, N.; Wollanski, E.; Burnett, W. C.; Perillo, G. M. E.; and Gornitz, V. 2005b. Dynamics of the coastal zone. In Crossland, C. J; Kremer, H. H.; Lindeboom, H. J.; Marshall Crossland, J. I.; and Le Tissier, M. D. A., eds. Global fluxes in the Anthropocene. Berlin, Springer, p. 39-94.

Syvitski, J. P. M.; Kettner, A.; Peckham, S. D.; and Kao, S.-J. 2005c. Predicting the flux of sediment to the coastal zone: application to the Lanyang watershed, northern Taiwan. I. Coast. Res. 21:580-587.

Syvitski, J. P. M.; Lewis, C. F. M.; and Piper, D. J. W. 1996. Paleoceanographic information derived from acoustic surveys of glaciated continental margins: examples from eastern Canada. In Andrews, J. T.; Austin, W. E. N.; Bergsten, H.; and Jennings, A. E., eds. Late Quaternary palaeoceanography of the North Atlantic margins. Geol. Soc. Spec. Publ. 111:51-76.

Syvitski, J. P., and Morehead, M. D. 1999. Estimating river-sediment discharge to the ocean: application to the Eel Margin, northern California. Mar. Geol. 154: $13-28$.

Syvitski, J. P. M.; Peckham, S. D.; Hilberman, R. D.; and Mulder, T. 2003. Predicting the terrestrial flux of sediment to the global ocean: a planetary perspective. Sediment. Geol. 162:5-24. Erratum for Sediment. Geol. 164:345.

Syvitski, J. P. M., and Saito, Y. Forthcoming. Morphodynamics of deltas under the influence of humans. Global Planet. Change.

Syvitski, J. P. M., and Shaw, J. 1995. Sedimentology and geomorphology of fjords. In Perillo, G. M. E., ed. Geomorphology and sedimentology of estuaries. Vol. 53. Developments in sedimentology. Amsterdam, Elsevier, p. 113-178.

Syvitski, J. P. M.; Vörösmarty, C.; Kettner, A. J.; and Green, P. 2005a. Impact of humans on the flux of terrestrial sediment to the global coastal ocean. Science 308:376-380.
Vizzoli, G. 2004. Erosion in the western Alps (Dora Baltea Basin). II. Quantifying sediment yield. Sediment. Geol. 171:247-259.

Vörösmarty, C.; Meybeck, M.; Fekete, B.; Sharma, K.; Green, P.; and Syvitski, J. P. M. 2003. Anthropogenic sediment retention: major global-scale impact from the population of registered impoundments. Global Planet. Change 39:169-190.

Walling, D. E. 1987. Rainfall, runoff, and erosion of the land: a global view. In Gregory, K. J., ed. Energetics of physical environment. Wiley, London, p. 89-117.

Walling, D. E., and Fang, D. 2003. Recent trends in the suspended sediment loads of the world's rivers. Global Planet. Change 39:111-126

Walling, D. E., and Webb, B. W. 1983. Patterns of sediment yield. In Gregory, K. J., ed. Background to hydrogeology. Chichester, Wiley, p. 69-100.

Wang, H.; Yang, Z.; Saito, Y.; Liu, J. P.; and Sun, X. 2006. Interannual and seasonal variation of the Huanghe (Yellow River) water discharge over the past 50 years: connection to impacts from ENSO events and dams. Global Planet. Change 50:212-225.

Wang, Y.; Ren, M.-e; and Syvitski, J. P. M. 1998. Sediment transport and terrigenous fluxes. In Brink, K. H., and Robinson, A. R., eds. The global coastal ocean: processes and methods. Vol. 10. The sea. New York, Wiley, p. 253-292.

Warrick, J. A., and Milliman, J. D. 2003. Hyperpycnal sediment discharge from semi-arid southern California rivers: implications for coastal sediment budgets. Geology 31:781-784.

Wilson, L. 1973. Variations in mean annual sediment yield as a function of mean annual precipitation. Am. I. Sci. 273:335-349.

Xu, K.; Milliman, J. D.; Yang, Z.; and Wang, H. 2006. Yangtze sediment decline partly from Three Gorges Dam. EOS: Trans. Am. Geophys. Union 87:185-190.

Yang, Z.; Wang, H.; Saito, Y.; Milliman, J. D.; Xu, K.; Qiao, S.; and Shi, G. 2006. Dam impacts on the Changjiang (Yangtze River) sediment discharge to the sea: the past 55 years and after the Three Gorges Dam. Water Resour. Res. 42, WO4407, doi:10.1029/ 2005WR003970. 